\title{
Prophylactic and Therapeutic EBV Vaccines: Major Scientific Obstacles, Historical Progress, and Future Direction
}

\author{
Jing Cai ${ }^{1}$, Bodou Zhang ${ }^{1}$, Yuqi Li ${ }^{1}$, Wanfang Zhu ${ }^{2}$, Toshihiro Akihisa ${ }^{1,3}$, Wei Li ${ }^{4}$, Takashi Kikuchi ${ }^{4}$, \\ Wenyuan Liu ${ }^{2}$, Feng Feng ${ }^{1,5}$ and Jie Zhang ${ }^{1,5, *}$ \\ 1 School of Traditional Chinese Pharmacy, China Pharmaceutical University, Nanjing 210009, China; \\ 3220020316@stu.cpu.edu.cn (J.C.); 1821020421@stu.cpu.edu.cn (B.Z.); 3219020456@stu.cpu.edu.cn (Y.L.); \\ akihisa_toshihiro@yahoo.co.jp (T.A.); fengfeng@cpu.edu.cn (F.F.) \\ 2 School of Pharmacy, China Pharmaceutical University, Nanjing 210009, China; \\ 3119010060@stu.cpu.edu.cn (W.Z.); liuwenyuan@cpu.edu.cn (W.L.) \\ 3 Research Institute for Science and Technology, Tokyo University of Science, Chiba 278-8510, Japan \\ 4 Faculty of Pharmaceutical Sciences, Toho University, Chiba 274-8510, Japan; liwei@phar.toho-u.ac.jp (W.L.); \\ t.kikuchi@gly.oups.ac.jp (T.K.) \\ 5 Jiangsu Food and Pharmaceutical Science College, Huaian 223003, China \\ * Correspondence: 1020152495@cpu.edu.cn
}

\section{check for} updates

Citation: Cai, J.; Zhang, B.; Li, Y.; Zhu, W.; Akihisa, T.; Li, W.; Kikuchi, T.; Liu, W.; Feng, F.; Zhang, J. Prophylactic and Therapeutic EBV Vaccines: Major Scientific Obstacles, Historical Progress, and Future Direction. Vaccines 2021, 9, 1290. https://doi.org/10.3390/ vaccines 9111290

Academic Editors: Chiang Cheryl Lai-Lai and Eduardo Gomez-Casado

Received: 1 September 2021

Accepted: 3 November 2021

Published: 7 November 2021

Publisher's Note: MDPI stays neutral with regard to jurisdictional claims in published maps and institutional affiliations.

Copyright: (c) 2021 by the authors. Licensee MDPI, Basel, Switzerland. This article is an open access article distributed under the terms and conditions of the Creative Commons Attribution (CC BY) license (https:/ / creativecommons.org/licenses/by/ $4.0 /)$.

\begin{abstract}
The Epstein-Barr virus (EBV) infects more than 95\% of adults worldwide and is associated with various malignant tumors and immune diseases, imparting a huge disease burden on the human population. Available EBV vaccines are imminent. Prophylactic vaccines can effectively prevent the spread of infection, whereas therapeutic vaccines mainly stimulate cell-mediated immunity and kill infected cells, thus curbing the development of malignant tumors. Nevertheless, there are still no approved EBV vaccines after decades of effort. The complexity of the EBV life cycle, the lack of appropriate animal models, and the limited reports on adjuvant selection and immune responses are gravely impeding progress in EBV vaccines. The soluble gp350 vaccine could reduce the incidence of infectious mononucleosis (IM), which seemed to offer hope, but could not prevent EBV infection. Continuous research and vaccine trials provide deep insights into the structural biology of viruses, the designs for immunogenicity, and the evolving vaccine platforms. Moreover, the new vaccine candidates are expected to achieve further success via combined immunization to elicit both a dual protection of B cells and epithelial cells, and sustainable immunization against infected cells at several phases of infection.
\end{abstract}

Keywords: Epstein-Barr virus; vaccine; T cells; antibodies; oncogenic

\section{Introduction}

The Epstein-Barr virus (EBV), also known as human herpesvirus 4 (HHV4), is a large double-stranded DNA (dsDNA) virus that belongs to the gammaherpesvirus subfamily [1]. EBV is the first identified oncovirus [2,3], with the most potent host-cell-transforming ability among all infectious disease pathogens in vitro, infecting approximately 95\% of adults worldwide [4]. Most EBV infections occur in infants, establish a lifelong latent infection state, or reactivate into lytic replication under certain circumstances [5,6] (Figure 1). EBV induces the hyperactivation of T cells in adolescents and young adults, resulting in immune dysregulation. Primary EBV infection $[7,8]$ may cause infectious mononucleosis (IM) $[7,8]$, and the virus-induced overactivation of bone marrow cell cytokines may lead to hemophagocytic lymphohistiocytosis (HLH) [9]. In the later stages of infection, due to excessive immune responses, multiple autoimmune diseases arise, including multiple sclerosis (MS) [10], Sjogren syndrome (SS), systemic lupus erythematosus (SLE), dermatomyositis, rheumatoid arthritis (RA), inflammatory bowel disease (IBD), and type 1 diabetes mellitus (T1DM) [11]. EBV is also associated with various diseases and tumors, such 
as Burkitt's lymphoma [12,13], post-transplant lymphoid-promoting disease (PTLD), diffuse large B cell lymphoma (DLBCL), Hodgkin's lymphoma (BL) [14], nasopharyngeal carcinoma (NPC) [15], and 10\% of gastric carcinomas (GC) [16,17]. The World Health Organization (WHO) has listed EBV as a class I oncogenic virus [18,19], with approximately 200,000 new cases of tumors directly associated with EBV annually worldwide [20].

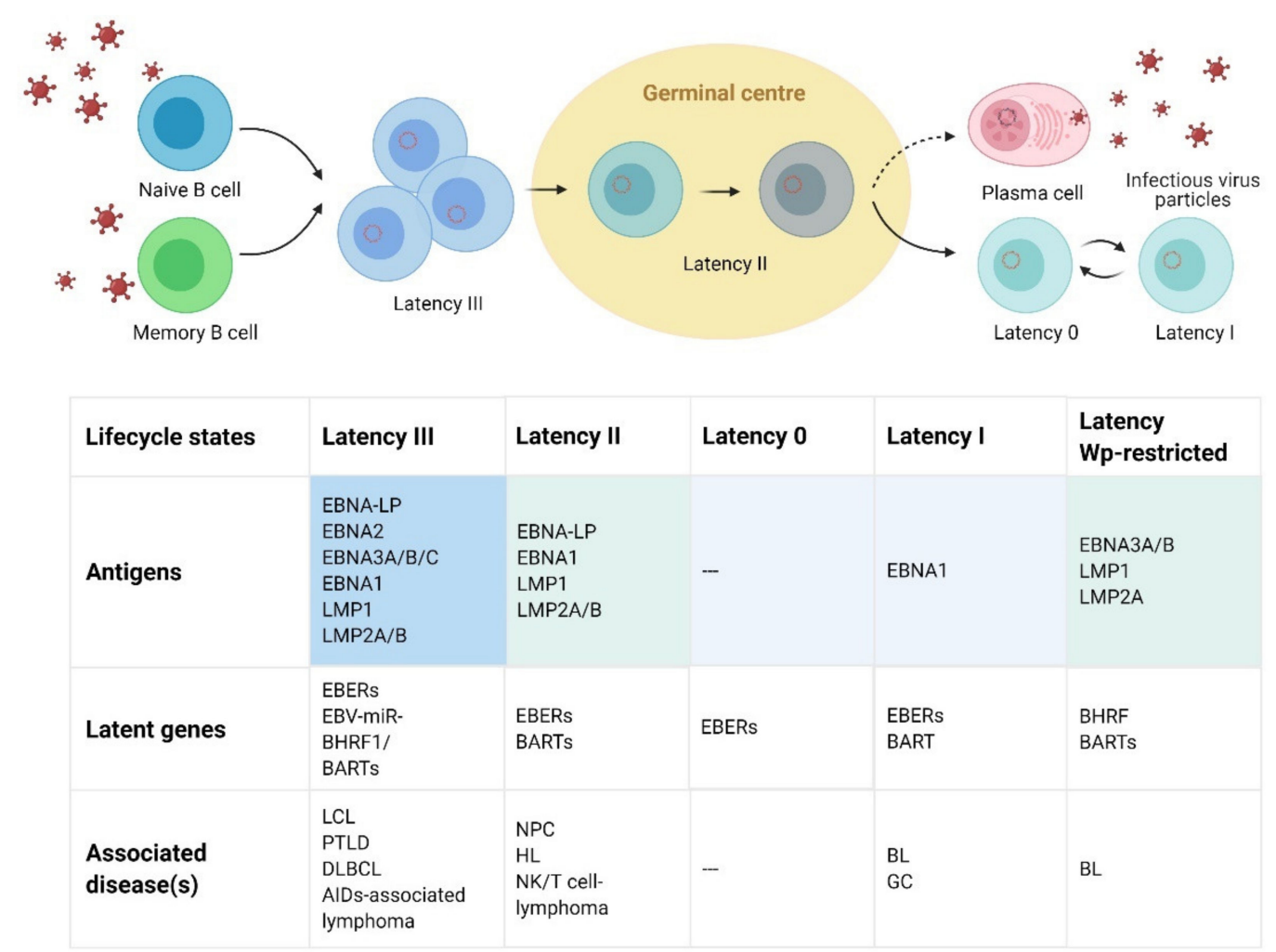

Figure 1. The phases of EBV infection in host cells and antigen expression. EBV in latent infection only expresses a minimal number of latent genes to maintain the stable presence of the virus' genome in cells and to promote the survival of infected cells while minimizing host immune recognition. According to the protein expression patterns, three latency phases have been identified, and the types and numbers of latent genes expressed by each phase differs. Latency III is the most elaborate viral expression phase (EBERs, EBNA-LP, EBNA1, EBNA2, EBNA3A-3C, LMP1, LPM2A, and LMP2B). It is commonly observed in cells in a highly clonal proliferative state, such as newly infected B cells or EBV-immortalized lymphoblastoid cell lines (LCLs). This phase is associated with the post-transplant lymphoproliferative disorder (PTLD), the spread of large B cell lymphoma (PT-DLBCL) after EBV transplantation, and AIDS-associated diffuse large B cell lymphoma. Latency II is more limited in protein expression (EBERs, EBNA-LP, EBNA1, LMP1, LMP2A, and LMP2B) and is associated with nasopharyngeal carcinoma (NPC), PT-DLBCL, Hodgkin's lymphoma (HL), and natural killer (NK)/T cell lymphoma. Latency I, the strictest latency phase (EBERs and EBNA1), can be found in proliferating memory B cells and is associated with post-transplant Burkitt lymphoma (BL) and gastric carcinoma (GC). Latency 0 is commonly in resting memory B cells without the expression of viral protein components. Moreover, the Wp-restricted latency phase (EBNA3A/3B, LMP1, and LMP2A) is associated with BL. In addition, non-coding RNA transcription of EBV in the state of latent infection exists. Figure created with BioRender.com.

The most effective way to control EBV prevalence is an EBV vaccine that should be safe, effective, and cost-effective. Considering the complex life cycle of EBV, some attempts have been made using EBV envelope proteins, latent antigens, and early lytic antigens. Unfortunately, there are still no licensed EBV vaccines after more than 50 years of effort [21,22]. This review aims to retrospect past and current vaccine progress, highlight knowledge gaps, and propose new directions and novel strategies for developing efficacious EBV vaccines. 


\section{EBV Virologic Features and Lifecycle}

EBV is a dsDNA virus [23-25] with a diameter of approximately $170 \mathrm{~nm}$, and consists of three basic parts: the lipid bilayer envelope, the pseudo-icosahedral nucleocapsid, and the middle pleomorphic tegument compartment [26-28]. The EBV 172-kb dsDNA genome is enclosed in the pseudo-icosahedral nucleocapsid. The pleomorphic tegument compartment in the middle contains $20-40$ different viral proteins, and the viral glycoprotein at the lipid bilayer envelope is responsible for host recognition and membrane fusion $[25,27,29]$.

EBV is mainly transmitted through saliva. After transfer across the mucosal epithelium, the virus infects B cells in secondary lymphoid tissues, such as the tonsils $[8,30]$. After infection, the virus injects the viral genome into the host cell nucleus through nuclear pore complexes, and the linear genome is circularized into the episomal form through terminal repeats [31]. During the primary infection, immature B cells are infected with EBV and then express EBV nuclear antigens, such as EBNA1, EBNA2, EBNA3A-EBNA3C, EBNA-LP, latent membrane protein 1 (LMP1), and LMP2, as well as EBV-encoded small RNAs (EBERs) and microRNA that activate latent $B$ cells and encourage them to proliferate and transform (latency III) [32]. Alternatively, the virus stimulates the infected memory B cells to differentiate directly into latency 0 . The virus can downregulate its immunogenic proteins and thus survive in B cells. B cells infected with EBV enter the follicle, amplify, form germinal centers, and express only three viral proteins (EBNA1, LMP1, and LMP2) (latency II). Then, they leave the lymph nodes and only express EBNA1 to separate the viral genome from the cell genome (latency I). When EBV-infected cells enter the peripheral blood, they shut down all of the viral genes (latency 0 or latency program). Hence, such EBV-infected resting memory cells are immune to the attack by the host's immune system and could serve as sites for long-term viral persistence [16,33]. After reactivation into the lytic phase, the EBV genome is amplified up to 1000-fold by the viral replication machinery [34]. The immediate-early lytic proteins Zta and Rta are expressed [35], thereby activating transcription factors, regulating the expression of the early lytic proteins BMRF1, BALF1, and BHRF1, and promoting the replication starting point Ori-lyt to trigger EBV genomic DNA replication. Structural proteins are then expressed, such as the matrix protein, capsid components, and envelope proteins. The viral genomic DNA produced by replication and the newly synthesized viral structural proteins are assembled into new infectious virus particles that are finally released outside the cell through exocytosis or cell lysis $[34,36]$.

\section{Immune Responses to EBV Infection}

\subsection{Humoral Immune Responses}

Primary EBV infection triggers a humoral immune response in the majority of infected individuals. B cells participate in the adaptive immune response and produce specific antibodies. The induction of immunoglobulin (Ig) M antibodies against viral capsid antigen (VCA) occurs in the early stage of infection and is maintained for weeks to months. After this, they switch to anti-VCA IgG antibodies that usually peak at two to four months after infection. The antibodies then decline and could last for a lifetime [37,38]. After the primary infection subsides, non-neutralizing targets, such as immediate-early and early antigens (BZLF1, BMRF1, BHRF1, BLRF2, BFRF3, gp42 [39], and EBNA 1, 2, and 3 [40]), appear. B cells also produce anti-EBNA1 IgG antibody and IgG/IgA antibodies against glycoprotein 350 (gp350) [39,41,42]; the gp350 antibody prevents EBV from binding to the CR2 receptor of B cells, limiting EBV transmission and reinfection [43-45]. In the latent infection phase, antigen-specific T cells, such as EBNA3A, $-\mathrm{B}$, and $-\mathrm{C}$, expand in vivo. The $\mathrm{T}$ cell function is inhibited in some patients with bone marrow suppression or organ transplantation who are prone to EBV-related lymphoproliferative diseases after transplantation [46,47].

\subsection{Cellular Immune Responses}

Several subsets of innate human lymphocytes target different stages of EBV infection. $\mathrm{CD} 8+\mathrm{T}$ cells play an essential role in the adaptive cellular immune response. IM symptoms 
are thought to be caused by the increase in CD8+ T cell-related activities. Studies in both immunocompromised transplant patients and individuals with a primary immunodeficiency have demonstrated the critical role that CD8+ T cells play in controlling the outgrowth of EBV-transformed B cells [48]. They mainly recognize lytic EBV antigens expressed during the immediate-early stages (e.g., BZLF1 and BRLF1) and early stages of lytic infection (e.g., BMLF1 and BMRF1, BALF2, and BALF) [49] to effectively control EBV infection and lymphoproliferative diseases after transplantation, especially in the early stage of lytic infection. After IM subsides, the response to the lytic phase antigen shrinks, usually accounting for $0.2-2 \%$ of the total number of CD8+ T cells in latent infected individuals. In contrast, the response of $\mathrm{T}$ cells to the latent phase antigen peaked after the remission of acute IM symptoms, typically accounting for $0.05-1 \%$ of the CD8+ T cells [50-52]. Antigen-specific CD8+ T cells are mainly stimulated by EBNA1 and other latent proteins. EBNA1 inhibits recognition by CD8+ T cells by inhibiting the pre-mRNA processing of the primary EBNA-1 transcript and inducing the retardation of self-translation. EBNA1 has also been shown to be protected from proteasomal degradation, thus achieving immune evasion [53-55].

CD4+ T cells also play an essential role in controlling EBV infection. EBV-infected B cells widely express MHC-II molecules and activate CD4+ T cells. EBV-specific CD4+ $\mathrm{T}$ cell responses are readily identifiable against soluble lytic antigens (BZLF1, BMLF1, and BCRF1), the envelope components (gp350 and gp110) [56-60], and the potential latent antigens (EBNA 1, 2, 3C, and LMP2) [48]. CD4+CTLs recognize antigens in EBV lytic/latent phases and kill infected B cells and LCLs through Fas/FasL interactions [61]. It often takes several months after infection for EBNA1 to stimulate an immune response by CD4+ T cells, explaining the delayed emergence of anti-EBNA1-IgG. Moreover, many CD4+ T cells that are specific for soluble antigens are perforin-positive and cytotoxic, suggesting that these cells may play a direct role in controlling viral replicative damage [48].

Similar to CD8+ T cells, NK cells expand significantly during IM $[62,63]$. NK cells preferentially recognize lytic EBV-replicating cells [64-66] and identify EBV-infected B cells that are not matched to MHC class I to control EBV infection [67]. Therefore, NK cells are preferred for targeting lytic EBV replication. Targeting other stages of EBV infection in the allogeneic environment could also be beneficial. V $\gamma 9 \mathrm{~V} \delta 2 \mathrm{~T}$ cells are elevated in EBV-positive children (25-50\%) [67]. They preferentially recognize EBV latency I-infected $\mathrm{B}$ cells, and, once activated, V $\gamma 9 \mathrm{~V} \delta 2 \mathrm{~T}$ cells can also target other EBV latency phases, including latency III carrying EBV-transformed LCLs. V $\gamma 9 \mathrm{~V} \delta 2 \mathrm{~T}$ cells complement NK cells by recognizing potential EBV infection [7]. A combination of two cytotoxic innate lymphocyte subsets may be beneficial for targeting EBV infection. NK T cells have a limited response to latency phase cells but preferentially recognize latency II. It is associated with extranodal NK/T-cell lymphoma-nasal type and aggressive NK-cell leukemia [68]. The immune control of EBV infection depends on these cytotoxic lymphocyte subsets that can be stimulated by an EBV-specific vaccine targeting different EBV-positive malignancies.

\section{EBV Transmission: Extensive and Rebellious}

The content of EBV DNA in the saliva of primary infected persons may be very high and persist for months, supporting the hypothesis that EBV infection in adolescents is primarily caused by deep kissing [69-71]. Besides sexual intercourse [72], the exchange of blood products, such as hematopoietic cell transplantation [73] and solid organ transplantation [74], can also promote EBV transmission and even cause IM [75-77]. However, the exact incidence is uncertain, and the risk does not appear to be high. A large number of EBV infections occur in infants and children, and the mechanism is still unclear. A reasonable hypothesis is that these infections originate from close contact with parents, relatives, or caregivers. EBV is regularly released into the oral secreta of the "carriers" [78,79]. In South Africa, children use saliva to wash their faces, gargle, and eat pre-chewed food [80], all of which could increase the likelihood of infection with EBV.

The prevalence of EBV infection in adults worldwide is as high as approximately 95\%, making it difficult or even impossible to limit exposure to EBV to contain the spread of 
primary EBV infection. Protection against EBV infection is imminent. An EBV vaccine would be the most effective way to control the EBV epidemic scientifically, but there are still no approved EBV vaccines after decades of effort. Nevertheless, it is still urgent to further promote the development of EBV vaccines.

\section{Challenges in EBV Vaccine Development}

\subsection{Immunization Surveillance and Efficacy Assessment}

Preventive and/or therapeutic EBV vaccines are designed to induce humoral and/or cellular immune responses to enhance treatment-related immune reactions. The complete prevention of EBV infection seems an elusive goal. If a vaccine provides only temporary immune protection or delays primary EBV infection, the virus will eventually go into uncontrolled lytic replication and could contribute to the occurrence of IM [8,81]. Thus, establishing or maintaining immune control against asymptomatic persistent EBV infection is the goal of EBV prophylactic vaccination [82,83]. The major problems with the development of a therapeutic EBV vaccine are the low incidence and sample sizes (fewer than 50 per 100,000 individuals [15]) in malignancies, as well as the inaccurate long-term assessment of vaccine efficacy due to the established immunosuppressive mechanism in vivo.

Since Epstein first proposed a vaccine in 1976 [21,22], several preventive and therapeutic vaccine strategies have been evaluated in clinical trials $[84,85]$. However, none have achieved the desired immune efficacy. The key index of preventive immunity is the neutralizing antibody (nAb) titer [86,87]. Neutralizing antibodies can effectively block the attachment of the virus to host receptors and the fusion between them, and a higher titer theoretically indicates that the antiviral infection effect is very evident. However, the value of this index in predicting the incidence of malignancy remains unclear $[88,89]$. The $\mathrm{T}$ cell response is also a critical component limiting EBV latent infection and the adaptive immune response [90-95]. Other EBV antigens need to be used in vaccine combinations to improve the vaccine efficacy, especially those with specific CD4+ and CD8+ T cell responses. In vitro studies have shown that CD4+ T cells specific for gp350 and other virus particles could recognize B cells very soon after EBV infection. Other EBV antigens, such as EBNA2, EBNA-LP, and LMPs, can be used as targets for CD8+ T cells. EBV vaccines against multiple immune responses to viruses can provide more comprehensive protection and control the immunological surveillance of primary infection and EBV-associated malignancies. Some knowledge gaps still need to be addressed, and further research is required to determine the role of the vital immunological components of EBV immunity establishment, including the role of B cell immunity during primary infection [96-98], T-cell-mediated immunity during latent infection [97], and the implementation of more relevant target antigens against EBV immunity [99].

\subsection{Adjuvant Selection}

Adjuvants modulate the immune efficacy of EBV vaccine formulations by enhancing the initial protection against primary infection and secondary protection against the reactivation or expansion of latent infection. Adjuvants, such as Freund's adjuvant, lipid A, immune-stimulating complexes (ISCOMS), and aluminum hydroxide, have been used to formulate gp350 vaccines [100-104]. Some of them have shown a better immunization efficacy than those without adjuvants. More complex adjuvants have entered preclinical and clinical trials. The level of antibodies induced by gp350/aluminum hydroxide and 3-Odesacyl-4'-monophosphoryl lipid A (AS04) is higher than that of traditional gp350/ALUM adjuvants [105], suggesting that an improved vaccine adjuvant combination might enhance the efficacy of an EBV vaccine. Therefore, vaccine combinations need more potent adjuvants to pre-stimulate immune recognition and improve both humoral and cellular immune responses. 


\subsection{Appropriate Animal Models}

A suitable animal model can provide a potential and critical platform for evaluating immune mechanisms and can target antigens for the prevention/control of EBV infection after vaccination. Meanwhile, EBV infection is highly species-specific, resulting in a lack of sufficient animal models for preclinical evaluation and an accurate understanding of the clinical relevance of protection and uncertainties in ancillary choices. The early gp350 vaccine candidates were tested for safety and immunogenicity using non-human primate (NHP) cotton-top tamarins and common marmosets (Callithrix jacchus) that have a high degree of homology to human genes $[106,107]$. However, these NHPs are critically endangered and are no longer available. The rhesus macaque is an applicable animal model for evaluating EBV-specific T cell responses [108-110], while the virus cannot effectively infect its B cells [111]. Moreover, the rhesus macaque is sensitive to LCV (i.e., rhLCV), which has a high genome sequence similarity to EBV [112]. When challenged with rhLCV, protected rhesus monkeys showed higher plasma anti-EBV gH/gL neutralizing antibody AMMO1 neutralization activity. This result showed that the soluble LCV gp350 vaccine in rhesus monkeys reduced both EBV infection and long-term viral load incidence [113].

Rabbits can also be used as potential animal models to test the efficacy of EBV vaccines against primary and persistent infection [114-117]. After infection through the veins or mucous membranes, the anti-EBV VCA titer and EBV DNA level can be detected in most rabbits' blood. However, the infection status is unstable, with only some rabbit spleen samples showing positivity for EBERs, LMP1, or EBNA, and few rabbits maintaining EBV-positive infections.

The mouse immune model is mainly used to evaluate the titer of serum and neutralizing antibodies [118-120]. A severely immunocompromised mouse model with a human immune system was established by transferring CD34+ hemopoietic stem cells [121-124]. After vaccination in a humanized mouse model, reconstructed human immune components (such as T cells, B cells, and dendritic cells [DCs]) are crucial mediators for inducing adaptive immune responses and promoting effective immunity. A humanized mouse model can also evaluate the protective effect of AMMO1, with the results showing that antibodies can effectively inhibit EBV infection [125].

\subsection{The Complexity of EBV Infection and Vaccine Design}

EBV can infect various cell types, but only details regarding $B$ cell and epithelial cell infection are known. EBV infects B cells and epithelial cells via a different set of glycoproteins (i.e., gp350, gp42, gH, gL, and gB). These glycoproteins are excellent vaccine targets [126-129]. However, it is unclear whether EBV vaccines should target multiple glycoproteins to effectively block EBV infection in various cell types [128,129]. Moreover, EBV can infect T cells $[130,131]$ and NK cells [132] through as-yet undefined mechanisms, suggesting that EBV vaccines cannot currently be properly designed to prevent the infection of all susceptible cell types. Structural proteins can be recognized not only by neutralizing antibodies but also by $\mathrm{T}$ cell reactions. Infected $\mathrm{B}$ cells are recognized by envelope (e.g., gp350, gH, and gB)- and tegument (e.g., BNRF1)-specific CD4+ T cells [133-135]. Thus, vaccines containing structural antigens, in addition to producing neutralizing antibodies, may also trigger protective $\mathrm{T}$ cell responses that target the virus and newly infected cells in early infection.

Infected B cells are recognized to varying degrees by latent (e.g., EBNA2 and EBNALP) and lytic (e.g., BHRF1) protein-specific CD4+ and CD8+ T cells [133]. For example, EBNA2 MHC-I-restricted epitopes are most effectively-identified early, indicating that the latent protein EBNA2 is a promising vaccine target. Potential antigens are present in EBV-associated diseases and malignancies, making it possible to reduce the disease burden of EBV with a latent protein vaccine [136-138]. Vaccines that induce latent protein-specific responses may help to target EBV-infected cells before and after transformation. More than 80 lytic genes are expressed during the EBV lytic phase [139]. Lytic-replicating cells express many antigens, and $\mathrm{T}$ cells often recognize immediate-early, early, and 
late antigens $[51,140,141]$ and subject them to immune control. In addition, hydrolyticreplicating cells display viral glycoproteins on their surfaces, making them a potential target for antibody-dependent cytotoxicity (ADCC) [142-145]. Thus, lytic-replicating cells are subjected to cellular and adaptive immune responses.

In summary, EBV-associated diseases and malignancies may be reduced by vaccination against EBV, but this may not achieve sterile immunity [20]. Live-attenuated vaccines are not suitable for EBV since live-attenuated herpesvirus may persist in infected individuals [146]. Further EBV vaccine exploration needs to take into account the complexity of EBV infection, such as the mechanisms of infection in different cell types, direct cell-tocell $[147,148]$, and the multiple antigens that predominate during EBV's life cycle, in order to ensure that the EBV vaccine is effective and safe.

\section{Progress: Where Are We Now?}

\subsection{Envelope Protein Vaccines: Neutralizing Antibodies Elicited}

By infecting the epithelial cells in the oropharynx, EBV is transported to B cells through blood vessels in the epithelial tissue and enters the latent infection phase [149]. At least five viral envelope glycoproteins (gp350, gB, gH, gL, and gp42) and three cellular proteins (CD21, HLA, and integrin) are required for EBV to enter B cells effectively. Gp350, the main component of the viral membrane, binds to the complement receptor type 2 (CD21) and type 1 (CD35) of B cells. The gp42 then forms a stable complex with $\mathrm{gH} / \mathrm{gL}$ and binds to human leukocyte antigen (HLA) class II to facilitate the endocytosis of the virion, and $\mathrm{gB}$ triggers the membrane to fuse with endocrine vesicles [43,150-152]. Other observations also show that gp350 is a target for ADCC [144,153], as well as for CD4+ T cell $[59,60]$ and CD8+ T cell responses [154]. Clinical trials have proven the safety and biological activity of the gp350 vaccine $[105,155]$. The EBV membrane antigen BNLF-1 MA (gp350/220) is also key to establishing EBV latent infection. Gp350/220 initiates the attachment of EBV to a susceptible host that expresses CD21 and/or CD35 [156]. The binding is further strengthened by the gp42 envelope protein interacting with MHC class II $[134,157]$. It is one of the antigenic candidates of EBV-preventive vaccine exploration (Figure 2). The main neutralizing antibody is the monoclonal antibody 72A1. It can block the EBV infection of $\mathrm{B}$ cells in vitro [158]. Other studies have shown that the EBV glycoproteins $\mathrm{gB}, \mathrm{gH}$, gL $[129,159,160]$, and gp42 [161] can also induce the production of protective neutralizing antibodies. Two prophylactic vaccines that induce neutralizing antibodies are currently under study [161,162].

EBV membrane antigens are often used as immunogens [163]. Gp350, due to its abundance, is the core antigen of the EBV vaccines currently under development [164-168]. The first clinical trial of the vaccinia construct expressing the EBV membrane antigen gp220-340 in China in 1995 demonstrated that gp220-340-specific antibodies could be elicited in both seronegative and seropositive children [169] (Table 1). The EBV live vaccine vector has shown some effectiveness. However, the sample size was too small to conclude its immune efficacy. Due to the safety concerns of live vaccinia vectors, no further research has been carried out on this method [170].

The recombinant subunit proteins expressed in Chinese hamster ovary $(\mathrm{CHO})$ cells have been used for making a gp350 candidate vaccine induce gp350 neutralizing antibodies successfully in rabbits [167]. This vaccine has been used in four clinical trials in humans and is still under development. In a phase I trial of the gp350 subunit vaccine [105], the safety and immunogenicity of three doses of the intramuscular vaccine containing $50 \mathrm{mg}$ of gp350 was evaluated in both EBV seropositive and seronegative adults. After immunization, all of the 22 seronegative subjects had specific immune responses to the vaccine and produced anti-gp350 antibodies, and the antibodies were more likely to be neutralized in subjects who received the vaccine in an adjuvant system 04 (AS04). In another phase 1/2 study, a total of 138 adult subjects aged 18-25 who were serologically negative or positive for EBV were randomized to receive the gp350 vaccine in an aluminum salt adjuvant, AS04, and no adjuvant [105]. All of the subjects developed an antibody titer for gp350 ELISA, 
and the vaccine inoculated with the AS04 adjuvant produced a higher neutralization titer. However, a suspected vaccine-related adverse event occurred. A subject positive for EBV antibodies who received the second dose of the AS04 adjuvant gp350 subunit vaccine was hospitalized with a significant autoimmune reaction involving the central nervous system and multiple joints.

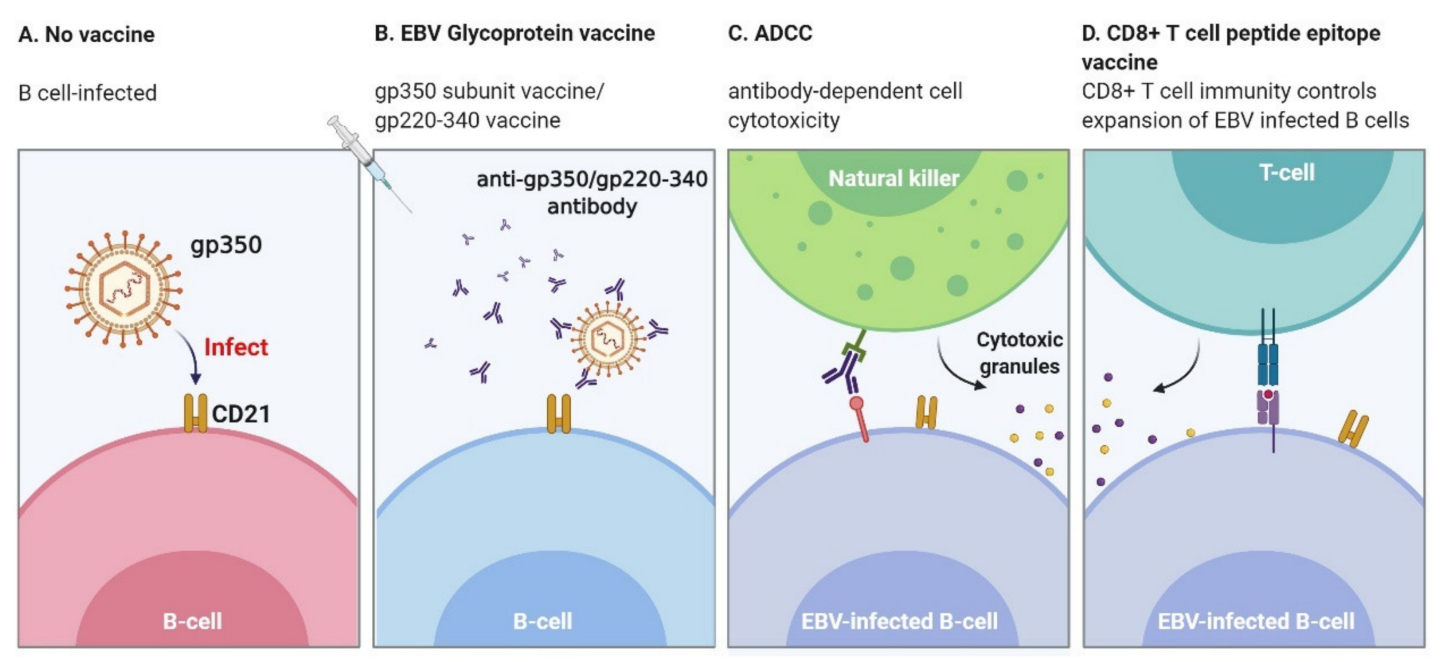

Figure 2. Mechanism of prophylactic vaccine action: (A) EBV virions bind to CD21 on B cells through gp350 and interact with HLA class II molecules to trigger gB-mediated viral-host membrane fusion within endosomes; (B) EBV membrane antigens are used as immunogens, and trigger neutralizing antibodies targeting virus particles to prevent the infection of host B cells; (C) the binding of antibodies with glycoprotein on the surface of infected cells can be recognized and eliminated by NK cells; (D) EBV-infected cells are recognized by T cells, which release cytotoxic granules and trigger the apoptosis of infected cells. Figure created with BioRender.com.

A placebo-controlled, double-blind, phase II clinical trial was conducted to test the safety, immune response, and efficacy of the AS04 recombinant gp350 vaccine. A total of 181 adolescent/adult subjects aged 16-25 years with a seronegative mononuclear disease risk were investigated [155]. The results showed that this vaccine had a significant effect on clinical disease, whereby $98.7 \%$ (76/77) of the vaccine recipients showed gp350 seroconversion lasting six months. This vaccine was $77.9 \%$ effective in preventing IM caused by EBV infection, and elicited anti-gp350 antibodies that were maintained in vivo for over 18 months. Despite these encouraging results, no evidence of protection against asymptomatic infection was found; 13 out of 90 vaccine recipients $(14.4 \%)$ were infected, compared to 18 out of 91 placebo subjects (19.8\%).

Finally, a phase I clinical trial of the recombinant gp350 subunit vaccine with an alumina hydroxide adjuvant was conducted in $16 \mathrm{EBV}$-negative children with chronic renal insufficiency who were awaiting renal organ transplantation [171]. Thirteen of the sixteen subjects produced gp350 antibody responses after inoculation, but only four subjects showed EBV-neutralizing antibody responses. These results show that the vaccine has good biological activity and immunogenicity, but a control group is unavailable for evaluating the curative effect. Additional doses of the vaccine and/or more effective adjuvants are still needed to shorten the time from the initial vaccination to organ transplantation in order to reduce the viral load of EBV in patients after transplantation, and to lower the risk of developing PTLD after transplantation immunosuppression.

The preventive vaccine with the viral envelope glycoprotein gp350 as the target antigen can effectively reduce the occurrence of IM, but it is not adequate for asymptomatic or specific EBV-infected persons [105,155]. This suggests that vaccination against the gp350 protein alone could not lead to complete protection. Therefore, improving antibody titers through adjuvant modification, the delivery of polymeric forms of gp350, or an increase in 
the diversity of neutralizing antibodies in combination with multiple proteins, such as $\mathrm{gB}$, $\mathrm{gH}, \mathrm{gL}$, and gp42, in order to prevent EBV infection, may be a future direction $[105,125]$.

\subsection{Protein Polymers and Nano-Vaccines Enhance the Response of Antibodies}

Cui et al. designed an EBV gH/gL trimer protein, a gH/gL monomer protein, a gB trimer protein, and a tetrameric gp350-based vaccine $[119,160,172]$ to induce neutralization antibodies after immunizing rabbits [160]. The tetramer used Gly4Ser1 3 as the linker for two identical gp350 sequences, and the self-binding action of the leucine zipper sequence of Saccharomycete GCN4 enabled the gp350 dimer containing the CD21 binding site to form the tetramer protein [171]. This tetramer gp350 vaccine enhances gp350-specific $T$ cell immunity and improves virus neutralization titers. Additionally, a high IgG titrant and strong anti-gp350 CD4+ T cell response have been detected in mice [114] inoculated with the GLA/SE adjuvant gp350 vaccine.

Kanekiyo et al. constructed nanoparticles based on EBV gp350 ${ }^{1-425}$ [44] that are not easily cleared by the immune system due to the lack of mucin regions in the 1-425amino-acid-residue gp350 glycoprotein. The authors tested this vaccine construct in mice and primates. The results have shown that the level of nanoparticles, after antigen immune protein-neutralizing antibodies, is higher than that for gp $350^{1-859}$ by approximately 10-100 times [44]. The application of nanotechnology provides a new method for developing an EBV-preventive vaccine. Notably, vaccinated animals did not become infected with EBV. However, it is unclear whether these neutralizing antibody titers would inhibit EBV infection in vivo.

In addition, a more efficient peptide vaccine containing a neutralizing epitope of the EBV envelope glycoprotein was established by epitope mapping. The investigators focused on inducing immune responses against the dominant neutralizing epitopes of gp350 and other envelope proteins through introducing strong ionic, electrostatic, or hydrogen bonding to the neutralizing region of mAb 72A1 [173] with computer modeling [174]. These biomimetic peptides blocked the interaction of the 72A1 antibody and gp350 in mice and elicited an antibody response.

To elicit a more comprehensive humoral immune response, the neutralizing anti$\mathrm{gH} / \mathrm{gL}$ antibody AMMO1 [129] that targets the EBV fusion machinery proteins, was isolated from memory B cells to produce a vaccine consisting of the envelope glycoprotein and viral fusion proteins. It showed a potent inhibition of $B$ cell and epithelial cell infections in vitro [128]. A nano-vaccine using tannic acid (TA) and EBV-related tumor protein antigens, with interferon- $\alpha$ (IFN- $\alpha$ ) or CpG as adjuvants [175,176], can significantly induce immune activation by targeting lymph nodes. Moreover, combining it with anti-PD-L1 resulted in a marked decrease in tumor size and prolonged the survival time of tumorbearing mice [175].

\subsection{CD8+ T cell Peptide Epitope Vaccine}

The prophylactic EBV vaccine can also control the EBV transmission by inducing cellmediated immune responses, such as specific CD8+ T cell responses to EBV latency EBNA proteins [177]. Elliott et al. made a CD8+ T cell peptide epitope-based vaccine that used FLRGRAYGL, an HLA-B*0801 restriction antigen epitope encoded by EBNA 3A, which can induce a specific CD8+ T cell immune response to EBNAs [125,178]. The vaccine was tested in a randomized, single-blind, placebo-controlled, single-center phase I clinical trial in 14 EBV-seronegative young adults [178]. The subjects received either EBNA-3A peptides with tetanus toxoid as an adjuvant with an oil-in-water emulsion (Montanide ISA 720) or the placebo at two-month intervals. Most of the subjects (8/9) with peptide-specific CD8+ T cell responses were shown to be effectively protected. Although this study was too small to determine the effectiveness of $\mathrm{T}$ cell immune induction in preventing primary symptomatic infection, it does demonstrate the feasibility of inducing cell-mediated immunity in health vaccinators by targeting EBV latency antigens. 
With a deeper understanding of $\mathrm{T}$ cell immunity in the control of EBV infection [60,179-182], the application of latent- or lytic-phase proteins as vaccine antigens has shown great potential in preclinical studies [183-187]. Several vaccine applications of latent- or lytic-phase proteins as vaccine antigen therapies expressed in malignancies are being developed in preclinical and early clinical trials [120,122,188,189].

\subsection{Vaccines}

The first clinical trial to evaluate the targeting of LMP antigens or EBNA1 was a vaccine trial based on dendritic cells (DCs). DCs are the most potent professional antigenpresenting cells that can activate resting $\mathrm{T}$ cells. DCs loaded with target peptides or proteins after culture and amplification in vitro can induce specific immune responses. In a phase I trial of therapeutic vaccination in 16 NPC patients [90], after four peptide-pulsed monocyte-derived DCs injections, nine patients had enhanced antigen-determine-specific CD8+ T cell responses that were associated with a slight decrease in serum EBV DNA levels. Tumor regression was observed in two of the nine patients [125]. A similar study of LMP2pulsed DCs by Lin et al. showed an increase in the LMP2 response [190]. Although this was not associated with a reduction in peripheral EBV load, the delayed hypersensitivity (DTH) did lead to a decrease in the EBV load. An alternative DC vaccine is made by transducing DCs with an adenoviral vector encoding the truncated LMP1 (Ad- $\triangle$ LMP1LMP2) [91]. Nine out of twelve NPC patients developed DTH responses in this phase II study of metastatic NPC-positive individuals. No change in the frequency of peripheral LMP-specific T cells was detected; three patients did show clinical responses, including partial remission (lasting 7.5 months), and two showed disease stabilization (lasting 6.5 and 7.5 months). These observations suggested that LMP-specific T cell responses may be induced after DC vaccination. However, the widespread use of DC vaccines is unfeasible, as the costs associated with personalized DC preparation can be high. A more appropriate approach might be to deliver the immunological determinants of LMP1, LMP2, and EBNA1 via viral vectors, or to formulate them in conjunction with adjuvants already licensed for use in humans.

\subsection{Viral Vector Vaccines}

Recombinant viral vector vaccines are live viruses that offer advantages over traditional vaccines. First, they can induce a wide range of immune responses [191,192] to effectively clear virus-infected cells and tumor cells, especially in CD8+ cytotoxic T cell (CTL) responses. Second, the body's natural immunity against live viruses has the effect of enhancing protective immune responses through the expression of a series of pathogenassociated molecular patterns (PAMPs) that elicit inflammatory responses. Third, viral vector vaccines have high gene transduction efficiencies [193]. Poxviruses, adenoviruses, and yellow fever viruses were developed as vaccine candidates [191]. However, the preexisting immunity from the human viral vectors needs to be considered. Vaccinia virus and adenovirus are among the most widely used viral vectors, mainly because of their ability to induce antigen-specific $\mathrm{T}$ cell responses.

The first EBV vaccine tested in humans used a live vaccinia recombinant vaccine expressing the EBV membrane antigen BNLF-1 MA (gp350) [169]. Although there was no significant change in the EBV infection between vaccinated and unvaccinated adults, EBV infection rates among vaccinated infants were reduced. This vaccine platform is no longer accepted due to the risk of adverse reactions [170].

A safer alternative viral vector is the multiplication-incompetent attenuated pox viral vector of the modified vaccinia virus Ankara (MVA) [194,195]. It has been used in vaccine clinical trials against other pathogens and can significantly induce $\mathrm{T}$ and $\mathrm{B}$ cell responses in human subjects with good safety. The recombinant EBV vaccinia Ankara virus strain vector vaccine (MVA-EL) was designed to encode a fusion protein of the 3' half of the EBNA1 gene and the full-length LMP2 gene [92,93]. Taylor et al. used the MVA-EL vaccine, which expressed partial EBNA1 and LMP2 proteins simultaneously 
in a phase I clinical trial [93]. In this study, EBV-positive NPC patients showed that the vaccine could effectively induce the expansion of EBNA1- and LMP2-specific CD4+ and CD8+ cells in the peripheral blood lymphocytes of EBV-seropositive patients. Eight of the fourteen patients had elevated levels of CD4+- and CD8+-specific $\mathrm{T}$ cell immune responses. Immuno-phenotypic analysis showed that EBNA1- and LMP2-specific CD4+ and CD8+ T cell differentiation and functional diversification could be induced by vaccination, proving that the vaccine has good immunogenicity and safety. The updated phase I clinical trial is designed to determine the safety, tolerability and immunogenicity of the extended schedule vaccination with MVA-EBNA1/LMP2 in EBV+ NPC patients [NCT01800071]. The same MVA-EL vaccine was tested in phase I clinical trials in EBV-positive NPC patients in Hong Kong [92], and was well-tolerated with no dose-limiting toxicity. Specific T cell responses were increased in 15 of the 18 patients, and the number of specific CTLs in the peripheral blood was increased by three to four times. The immune remission of patients lasted more than 12 weeks, but a small number of subjects experienced mostly grade 1 adverse reactions after receiving the vaccine. Only three patients experienced grades 2-3 adverse events.

Table 1. Illustration of completed and documented EBV vaccine trials.

\begin{tabular}{|c|c|c|c|c|c|}
\hline Vaccine & Year & Target Group & Immune Response & Result & Reference \\
\hline $\begin{array}{l}\text { Live recombinant } \\
\text { virus gp350 } \\
\text { vaccinia }\end{array}$ & 1995 & $\begin{array}{l}\text { Nine children that } \\
\text { were both } \\
\text { EBV-seropositive } \\
\text { and vaccinia-virus- } \\
\text { seronegative }\end{array}$ & $\begin{array}{l}\text { Vaccination boosted } \\
\text { EBV-neutralizing antibody } \\
\text { titers, but the target group was } \\
\text { too small to prove efficacy }\end{array}$ & No vaccine efficacy & {$[169,170]$} \\
\hline \multirow{2}{*}{$\begin{array}{l}\text { Recombinant } \\
\text { gp350 vaccine } \\
\text { produced in } \\
\text { Chinese hamster } \\
\text { ovary cells }\end{array}$} & 2007 & $\begin{array}{l}\text { EBV-seropositive } \\
\text { and seronegative } \\
\text { adults }\end{array}$ & $\begin{array}{l}\text { ELISA antibody titers to gp350 } \\
\text { were detected; higher efficacy } \\
\text { with MPL adjuvant }\end{array}$ & No vaccine efficacy & [105] \\
\hline & 2007 & $\begin{array}{l}\text { EBV-seronegative } \\
\text { adults }\end{array}$ & $\begin{array}{l}\text { ELISA antibody titers to gp350 } \\
\text { were detected; neutralizing } \\
\text { titers developed in } 50-60 \% \text { of } \\
\text { persons; higher efficacy with } \\
\text { alum adjuvant }\end{array}$ & $\begin{array}{l}\text { One serious } \\
\text { adverse event } \\
\text { occurred; no } \\
\text { vaccine efficacy }\end{array}$ & [105] \\
\hline $\begin{array}{l}\text { Recombinant } \\
\text { gp350 vaccine }\end{array}$ & 2007 & $\begin{array}{l}181 \text { EBV-negative } \\
\text { teenagers/adult } \\
\text { subjects }\end{array}$ & $\begin{array}{l}\text { Neutralizing antibodies were } \\
\text { detected; vaccine efficacy to } \\
\text { prevent infectious } \\
\text { mononucleosis by } 78 \% \text {, but no } \\
\text { prevention of EBV infection }\end{array}$ & $\begin{array}{l}\text { No serious adverse } \\
\text { events were } \\
\text { reported; prospects } \\
\text { for prevention of } \\
\text { Hodgkin's } \\
\text { lymphoma or MS. } \\
\text { No further reports }\end{array}$ & [155] \\
\hline $\begin{array}{l}\text { Recombinant } \\
\text { gp350 vaccine }\end{array}$ & 2009 & $\begin{array}{l}16 \text { pediatric } \\
\text { renal-transplant } \\
\text { EBV-seronegative } \\
\text { candidates }\end{array}$ & $\begin{array}{c}\text { Poorly immunogenic, probably } \\
\text { due to a low dose and weak } \\
\text { adjuvant }\end{array}$ & $\begin{array}{l}\text { The trial could not } \\
\text { assess protection } \\
\text { from PTLD }\end{array}$ & [171] \\
\hline $\begin{array}{l}\text { EBV peptide } \\
\text { vaccine }\end{array}$ & 2008 & $\begin{array}{l}14 \text { HLA B*801 } \\
\text { EBV-seronegative } \\
\text { young adults }\end{array}$ & $\begin{array}{l}\text { A CD8+ T cell peptide vaccine } \\
\text { was immunogenic with a hint of } \\
\text { efficacy }\end{array}$ & $\begin{array}{l}\text { No serious adverse } \\
\text { events occurred; } \\
\text { CD8+ T cell } \\
\text { peptide vaccine: } \\
\text { HLA restricted }\end{array}$ & {$[125,178]$} \\
\hline $\begin{array}{l}\text { EBV-specific } \\
\text { HLA-A2-restricted } \\
\text { DC vaccine }\end{array}$ & 2013 & $\begin{array}{c}16 \text { human } \\
\text { leukocyte } \\
\text { antigen-A2 } \\
\text { (HLA-A2)-positive } \\
\text { NPC patients }\end{array}$ & $\begin{array}{l}\text { Th1-specific immune responses } \\
\text { were elicited, particularly in } \\
\text { DTH test-positive individuals }\end{array}$ & $\begin{array}{l}\text { The vaccine was } \\
\text { well-tolerated; this } \\
\text { vaccination is a } \\
\text { promising } \\
\text { treatment for } \\
\text { EBV-related NPCs }\end{array}$ & [190] \\
\hline
\end{tabular}


Table 1. Cont.

\begin{tabular}{|c|c|c|c|c|c|}
\hline Vaccine & Year & Target Group & Immune Response & Result & Reference \\
\hline $\begin{array}{c}\text { Adenovirus } \\
\Delta \mathrm{LMP1}-\mathrm{LMP} 2 \\
\text { transduced DC } \\
\text { vaccine }\end{array}$ & 2012 & $\begin{array}{l}16 \text { metastatic NPC } \\
\text { patients }\end{array}$ & $\begin{array}{l}\text { Modified DC induced a } \\
\text { low-level immune response }\end{array}$ & $\begin{array}{l}\text { The potency of the } \\
\text { current vaccine } \\
\text { was too low for } \\
\text { significant benefits } \\
\text { in patients with } \\
\text { extensive disease }\end{array}$ & [91] \\
\hline $\begin{array}{l}\text { AdE1-LMPpoly } \\
\text { vaccine }\end{array}$ & 2012 & $\begin{array}{l}24 \text { EBV-positive } \\
\text { nasopharyngeal } \\
\text { carcinoma (NPC) }\end{array}$ & $\begin{array}{l}\text { Highly efficient in expanding } \\
\text { antigen-specific T cells from } \\
\text { patients with advanced } \\
\text { recurrent or metastatic NPC } \\
\text { disease, and these expanded T } \\
\text { cells displayed high levels of } \\
\text { functional capacity, as assessed } \\
\text { by IFN- } \gamma \text { expression }\end{array}$ & $\begin{array}{l}\text { The } \\
\text { AdE1-LMPpoly } \\
\text { vaccine was safe } \\
\text { and well-tolerated } \\
\text { and may offer } \\
\text { clinical benefits to } \\
\text { patients with NPC }\end{array}$ & [196] \\
\hline \multirow{2}{*}{$\begin{array}{c}\text { Ankara vaccinia } \\
\text { recombinant vector } \\
\text { expressing } \\
\text { EBNA-1 and LMP2 }\end{array}$} & 2013 & $\begin{array}{c}18 \text { EBV-positive } \\
\text { NPC }\end{array}$ & $\begin{array}{l}\text { CD4+ } \mathrm{T} \text { cell responses to one or } \\
\text { two vaccine antigens }\end{array}$ & $\begin{array}{l}\text { MVA-EL was both } \\
\text { safe and } \\
\text { immunogenic. } \\
\text { However, } \\
\text { therapeutic } \\
\text { efficacy has not yet } \\
\text { been assessed. The } \\
\text { highest dose is to } \\
\text { be examined in } \\
\text { phase II studies for } \\
\text { clinical benefits }\end{array}$ & [92] \\
\hline & 2014 & $\begin{array}{c}16 \text { EBV-positive } \\
\text { NPC }\end{array}$ & $\begin{array}{l}\text { CD4+ } \mathrm{T} \text { cell responses to one or } \\
\text { two vaccine antigens }\end{array}$ & $\begin{array}{l}\text { MVA-EL was safe } \\
\text { and immunogenic } \\
\text { across diverse } \\
\text { ethnicities and } \\
\text { thus suitable for } \\
\text { use in trials against } \\
\text { different } \\
\text { EBV-positive } \\
\text { cancers globally }\end{array}$ & [93] \\
\hline $\begin{array}{c}\text { Adenoviral } \\
\text { vaccine of } \\
\text { EBV-LMP2 } \\
\text { (rAd5-EBV-LMP2) }\end{array}$ & 2016 & $\begin{array}{c}24 \text { patients with } \\
\text { advanced regional } \\
\text { NPC }\end{array}$ & $\begin{array}{l}\text { Failed to significantly affect } \\
\text { peripheral CD8+ T cells }\end{array}$ & $\begin{array}{c}\text { The } \\
\text { rAd5-EBV-LMP2 } \\
\text { vaccine was safe } \\
\text { and well-tolerated, } \\
\text { but has no vaccine } \\
\text { efficacy }\end{array}$ & [95] \\
\hline
\end{tabular}

Considering the complexity of cell vaccine methods, the adenovirus vector encoding the EBV antigen could be considered for use to elicit pre-existing EBV-specific immunity. Adenovirus vectors encoding LMP2 are also in clinical development. Si et al. conducted a phase I clinical trial in NPC patients using a recombinant adenovirus vaccine carrying EBV LMP2 (rAd5-EBV-LMP2) [95]. Subjects were EBV IgA/VCA serum-positive with stable advanced NPC treated under routine chemotherapy. The results showed that CD3+ and CD4+ cells in the peripheral blood of immunized patients were dose-dependent. With no severe adverse reaction, this proves that the recombinant adenovirus vector vaccine has adequate safety. After two years of follow-up, $83.3 \%$ of the patients were non-progressive after vaccination, as compared to $80 \%$ after conventional chemo-radiotherapy.

DCs or EBV-transformed B lymphocyte lines could be infected in vitro with or without EBNA1 using vectors encoding LMP to expand the EBV-specific T cell response [196]. Hartlage et al. inoculated SCID mice (injected with human peripheral blood mononuclear cells with an EBV-seropositive donor) with Zta-expressing adenovirus or DCs transduced by an 
adenovirus with empty vectors. Compared to the control group, mice that received DCs expressing Zta produced Zta-specific T cell responses and showed a delayed development of the lymphoproliferative disease of EBV [122].

\subsection{Virus-Like Particles (VLPS)}

Virus-like particles (VLPs) can induce neutralizing antibody targets. Compared to recombinant antigens, VLPs have a potential advantage because they can mimic the natural structure of the virus while not containing viral DNA [135]. Terminal repeats (TRS) were identified as packaging signals for EBV DNA [197,198], and the first generation of cell lines producing EBV VLPs was formed by removing TRS. EBV VLPs can bind human B and epithelial cells. Ruiss et al. prepared a viral material with a structure similar to EBV and obtained a cell line based on it [199]. The cell line has been genetically modified to contain viral proteins that are only essential for assembly and release. This material has a strong immunogenicity and can effectively stimulate the immune responses of CD4+ and CD8+ T cells in vivo. Pavlova et al. demonstrated that the deletion of BLFL1 and BRRF1A genes promoted DNA-free EBV VLPs with a certain immunogenicity [134]. Compared to the BFLF1/BFRF1A mutant EBV strain used as the wild type [134] that elicited comparable CD4+ $\mathrm{T}$ cell responses, the pathogenic potential of EBV VLPs was reduced. However, immune responses to EBV structural and disintegrated components were insufficient in generating an effective EBV vaccine. Moreover, Ogembo et al. found that human complement receptor 1 (CD35) can also be used as an EBV receptor, and constructed viruslike particles with EBVgp350/220 chimerism (VLP-subunit vaccine) [189]. The vaccine produced persistent neutralizing antibodies in mice. However, the serum antibody titer was slightly lower than the UV-EBV titer of the control group (EBV inactivated by $254 \mathrm{~nm}$ UV for $5 \mathrm{~min}$ ), possibly due to the misfolding of the surface proteins of VLPs caused by the insertion of foreign genes that reduced the immunogenicity.

A chimeric VLP based on the hepatitis B core antigen (HBc149) has been designed [200]. All HBc149 proteins self-assemble into VLPs with gp350 epitopes displayed on the surfaces of spherical particles. The different orders of the three epitopes in the chimeric proteins induced different immune responses in Balb/C mice. Two constructs (149-3A and 149-3B) induced a high serum titer against the receptor-binding domain of gp350 and elicited neutralizing antibodies in immunized mice, which efficiently blocked EBV infection in cell cultures. Competition analysis has shown that the sera from these mice contained antibodies to a major neutralizing epitope recognized by the neutralizing mAb 72A1. HBc149 chimeric VLPs provide a valuable platform for presenting EBV gp350 antigens and offer a robust basis for developing peptide-based candidate vaccines against EBV.

\subsection{Nucleic Acid Vaccines}

To maximize the probability of $\mathrm{T}$ cells (including $\mathrm{CD} 4+$ and $\mathrm{CD} 8+$ ) recognizing viruses, overlapping PCR technology has been used to integrate the genes encoding for EBV EBNA1, LMP1, and LMP2. They have been inserted into adenovirus expression vectors to activate CD4+ and CD8+ T cells in NPC immunotherapy [196,201]. Li et al. reported that, after initial immunization with a DNA vaccine containing the LMP2 gene, the immunogenicity was enhanced compared with the LMP2 epitope peptide vaccine containing polypeptides. It binds to CTLs, T helper cells, B cells, and mouse-restricted CTL-binding poly-peptides, resulting in cellular immune responses [202].

Beyond this, the development of CRISPR/Cas9 genome-editing techniques are providing novel strategies for combating productive and latent EBV infections, such as viral genetic elements needed to target viral adaptability [203]. Lebbink et al. demonstrated that the virus could be almost eliminated from EBV-transformed cells with latent infection by simultaneously targeting the EBV genome with multiple guided RNA (gRNA) [204]. This provided a new way for developing therapeutic approaches for pathogenic human herpesvirus through new genomic-engineering techniques, such as antiviral drugs and other small molecules. Noh et al. targeted EBNA1 and used the transcriptional activation inducer 
E1TN to target the EBNA1 gene [205], inducing the gradual apoptosis of EBV-positive B cells, while leaving the EBV-negative cells unaffected. In addition, mRNA vaccines, as an effective, rapid, and universal vaccine platform, have attracted much attention in recent years, especially with the emergence of the COVID-19 mRNA vaccine. However, EBV mRNA vaccine development is still in its early stages. Moderna announced its ambitions for EBV mRNA vaccine development, with candidates for the major EBV glycoproteins gp350, gB, gH/gL, and gp42 [206].

\section{Conclusions and Outlooks}

For centuries, vaccines have been used to prevent and treat various diseases, and widespread vaccination has saved millions of lives by successfully eradicating smallpox and significantly reducing other infectious diseases [207,208]. Traditional vaccine formulations, such as subunit vaccines, attenuated live vaccines, and inactivated pathogens vaccines, that provide strong protection against many deadly diseases, are unsuitable for EBV [209,210]. The low levels of neutralizing antibody titers elicited by gp350 subunit vaccines are insufficient to induce adequate immune protection [154,170]. Future vaccines must adopt multipronged approaches capable of stimulating more than one arm of the immune system. Reasonable approaches involve improving adjuvants, protein-polymer formations, enhancing antibody diversity, or developing novel strategies, such as targeted B cell precursors that produce broadly neutralizing antibodies, novel viral vectors, and multivector sequential vaccines. The presence of viruses in EBV-positive tumor patients provides a target for tumor immunotherapy, and improving the level of specific CTLs is the focus of EBV therapeutic vaccine development. Viral vectors carrying the EBV gene, DCs, and other antigen-presenting cells loaded with EBV-related proteins or epitope polypeptides have been used to induce and activate the corresponding CTLs of patients and clear tumor cells. Meanwhile, passive immunotherapy includes directly activating patient-specific CTLs or modifies CTLs in vitro and infusing them back to the patient. Immunotherapy used in combination with clinical conventional radiotherapy and chemotherapy is expected to prevent the recurrence or metastasis of tumors.

The complexity of the EBV life cycle, the lack of suitable animal models, and our limited understanding of the immune response needed to prevent EBV infection have hindered the progress in vaccine development. There is still reason for cautious optimism that the numerous current clinical or preclinical developments for vaccine candidates will lead to further success, although this success may be modest and iterative. The valuable knowledge accumulated from numerous basic and translational science studies and vaccine trials has provided insight into the structural biology of viruses, immunogenic design, and novel vaccine delivery systems that may constitute effective vaccines. Further insights from humoral or cellular immunity levels may inspire immunotherapies targeting the pathology associated with different EBV infection processes. Multiple stimulations of the immune system require active efforts to seek combination vaccination methods in order to induce innate and adaptive immune responses. Gene editing and nanomaterial technology will also help to propel the development of an EBV vaccine.

Author Contributions: Conceptualization, investigation, writing, and original draft preparation, J.C.; data curation and validation, B.Z., Y.L., and W.Z.; project administration and supervision, T.A., W.L. (Wei Li), and T.K.; supervision, W.L. (Wenyuan Liu) and F.F.; resources, funding acquisition, reviewing, and editing, J.Z. All authors have read and agreed to the published version of the manuscript.

Funding: This research was funded by the "Double First-Class" University project (grant no. CPU2018GY34).

Institutional Review Board Statement: Not applicable.

Informed Consent Statement: Not applicable. 
Data Availability Statement: The data presented in this study are available on request from the corresponding author.

Conflicts of Interest: The authors declare no competing financial interests.

\section{References}

1. Farrell, P.J. Epstein-Barr Virus and Cancer. Annu. Rev. Pathol. 2019, 14, 29-53. [CrossRef]

2. Lieberman, P.M. Epstein-Barr virus turns 50. Science 2014, 343, 1323-1325. [CrossRef] [PubMed]

3. De-The, G.; Geser, A.; Day, N.E.; Tukei, P.M.; Williams, E.H.; Beri, D.P.; Smith, P.G.; Dean, A.G.; Bronkamm, G.W.; Feorino, P.; et al. Epidemiological evidence for causal relationship between Epstein-Barr virus and Burkitt's lymphoma from Ugandan prospective study. Nature 1978, 274, 756-761. [CrossRef] [PubMed]

4. Münz, C. Latency and lytic replication in Epstein-Barr virus-associated oncogenesis. Nat. Rev. Microbiol. 2019, 17, 691-700. [CrossRef] [PubMed]

5. Chen, Y.; Fachko, D.N.; Ivanov, N.S.; Skalsky, R.L. B Cell Receptor-Responsive miR-141 Enhances Epstein-Barr Virus Lytic Cycle via FOXO3 Inhibition. mSphere 2021, 6, e00093-21. [CrossRef] [PubMed]

6. Chen, Y.; Fachko, D.; Ivanov, N.S.; Skinner, C.M.; Skalsky, R.L. Epstein-Barr virus microRNAs regulate B cell receptor signal transduction and lytic reactivation. PLoS Pathog. 2019, 15, e1007535. [CrossRef]

7. Münz, C. Epstein-Barr Virus-Specific Immune Control by Innate Lymphocytes. Front. Immunol. 2017, 8, 1658. [CrossRef] [PubMed]

8. Dunmire, S.K.; Verghese, P.S.; Balfour, H.H., Jr. Primary Epstein-Barr virus infection. J. Clin. Virol. 2018, 102, 84-92. [CrossRef]

9. Al-Samkari, H.; Berliner, N. Hemophagocytic Lymphohistiocytosis. Annu. Rev. Pathol. 2018, 13, 27-49. [CrossRef]

10. Ascherio, A.; Munger, K.L.; Lunemann, J. The initiation and prevention of multiple sclerosis. Nat. Rev. Neurol. 2012, 8, 602-612. [CrossRef]

11. Toussirot, E.; Roudier, J. Epstein-Barr virus in autoimmune diseases. Best Practice \& Research. Clin. Rheumatol. 2008, 22, 883-896. [CrossRef]

12. Epstein, M.A.; Achong, B.G.; Barr, Y.M. Virus Particles in Cultured Lymphoblasts from Burkitt's Lymphoma. Lancet 1964, 1, 702-703. [CrossRef]

13. Epstein, M.A.; Henle, G.; Achong, B.G.; Barr, Y.M. Morphological and Biological Studies on a Virus in Cultured Lymphoblasts from Burkitt's Lymphoma. J. Exp. Med. 1965, 121, 761-770. [CrossRef]

14. Lung, M.L.; So, S.; Chan, K.; Lam, W.; Ng, M. Evidence That Respiratory Tract Is Major Reservoir for Epstein-Barr Virus. Lancet 1985, 325, 889-892. [CrossRef]

15. Shannon-Lowe, C.; Rickinson, A. The Global Landscape of EBV-Associated Tumors. Front. Oncol. 2019, 9, 713. [CrossRef] [PubMed]

16. Kutok, J.; Wang, F. Spectrum of Epstein-Barr Virus-Associated Diseases. Annu. Rev. Pathol. Mech. Dis. 2006, 1, 375-404. [CrossRef]

17. Fukayama, M. Epstein-Barr virus and gastric carcinoma. Pathol. Int. 2010, 60, 337-350. [CrossRef]

18. Parkin, D.M. The global health burden of infection-associated cancers in the year 2002. Int. J. Cancer 2006, 118, 3030-3044. [CrossRef]

19. Bouvard, V.; Baan, R.; Straif, K.; Grosse, Y.; Lauby-Secretan, B.; El Ghissassi, F.; Benbrahim-Tallaa, L.; Guha, N.; Freeman, C.; Galichet, L.; et al. A review of human carcinogens-Part B: Biological agents. Lancet Oncol. 2009, 10, 321-322. [CrossRef]

20. Cohen, J.I.; Fauci, A.S.; Varmus, H.; Nabel, G.J. Epstein-Barr Virus: An Important Vaccine Target for Cancer Prevention. Sci. Transl. Med. 2011, 3, 107fs7. [CrossRef]

21. Epstein, M.A.; Achong, B.G. The EB virus. Annu. Rev. Microbiol. 1973, 27, 413-436. [CrossRef]

22. Epstein, M.A. Epstein-Barr virus-Is it time to develop a vaccine program? J. Nat. Cancer Inst. 1976, 56, 697-700. [CrossRef]

23. Connolly, S.A.; Jardetzky, T.S.; Longnecker, R. The structural basis of herpesvirus entry. Nat. Rev. Microbiol. 2020, 19, 110-121. [CrossRef] [PubMed]

24. Liu, F.; Zhou, Z.H. Comparative virion structures of human herpesviruses. In Human Herpesviruses: Biology, Therapy, and Immunoprophylaxis; Arvin, A., Campadelli-Fiume, G., Mocarski, E., Moore, P.S., Roizman, B., Whitley, R., Eds.; Cambridge University Press: Cambridge, UK, 2007.

25. Nii, S.; Uno, F.; Yoshida, M.; Akatsuka, K. Structure and assembly of human beta herpesviruses. Jpn. J. Clin. Med. 1998, 56, 22-28.

26. Johannsen, E.; Luftig, M.; Chase, M.R.; Weicksel, S.; Cahir-McFarland, E.; Illanes, D.; Sarracino, D.; Kieff, E. Proteins of purified Epstein-Barr virus. Proc. Natl. Acad. Sci. USA 2004, 101, 16286-16291. [CrossRef] [PubMed]

27. Grünewald, K.; Desai, P.; Winkler, D.C.; Heymann, J.B.; Belnap, D.M.; Baumeister, W.; Steven, A.C. Three-Dimensional Structure of Herpes Simplex Virus from Cryo-Electron Tomography. Science 2003, 302, 1396-1398. [CrossRef] [PubMed]

28. Li, Z.; Zhang, X.; Dong, L.; Pang, J.; Xu, M.; Zhong, Q.; Zeng, M.-S.; Yu, X. CryoEM structure of the tegumented capsid of Epstein-Barr virus. Cell Res. 2020, 30, 873-884. [CrossRef] [PubMed]

29. Dai, W.; Jia, Q.; Bortz, E.; Shah, S.; Liu, J.; Atanasov, I.; Li, X.; Taylor, K.A.; Sun, R.; Zhou, Z.H. Unique structures in a tumor herpesvirus revealed by cryo-electron tomography and microscopy. J. Struct. Biol. 2008, 161, 428-438. [CrossRef]

30. Halder, S.; Murakami, M.; Verma, S.C.; Kumar, P.; Yi, F.; Robertson, E.S. Early Events Associated with Infection of Epstein-Barr Virus Infection of Primary B-Cells. PLoS ONE 2009, 4, e7214. [CrossRef] 
31. Paludan, S.R.; Bowie, A.G.; Horan, K.A.; Fitzgerald, K.A. Recognition of herpesviruses by the innate immune system. Nat. Rev. Immunol. 2011, 11, 143-154. [CrossRef]

32. Lieberman, P.M. Keeping it quiet: Chromatin control of gammaherpesvirus latency. Nat. Rev. Microbiol. 2013, 11, 863-875. [CrossRef] [PubMed]

33. Küppers, R. B cells under influence: Transformation of B cells by Epstein-Barr virus. Nat. Rev. Immunol. 2003, 3, 801-812. [CrossRef]

34. McKenzie, J.; El-Guindy, A. Epstein-Barr Virus Lytic Cycle Reactivation. Curr. Top. Microbiol. Immunol. 2015, 391, 237-261. [CrossRef] [PubMed]

35. Schelcher, C.; Valencia, S.; Delecluse, H.-J.; Hicks, M.; Sinclair, A.J. Mutation of a Single Amino Acid Residue in the Basic Region of the Epstein-Barr Virus (EBV) Lytic Cycle Switch Protein Zta (BZLF1) Prevents Reactivation of EBV from Latency. J. Virol. 2005, 79, 13822-13828. [CrossRef] [PubMed]

36. Murata, T. Regulation of Epstein-Barr virus reactivation from latency. Microbiol. Immunol. 2014, 58, 307-317. [CrossRef] [PubMed]

37. Hewetson, J.F.; Rocchi, G.; Henle, W.; Henle, G. Neutralizing Antibodies to Epstein-Barr Virus in Healthy Populations and Patients with Infectious Mononucleosis. J. Infect. Dis. 1973, 128, 283-289. [CrossRef] [PubMed]

38. Horwitz, C.A.; Henle, W.; Henle, G.; Rudnick, H.; Latts, E. Long-Term Serological Follow-Up of Patients for Epstein-Barr Virus After Recovery from Infectious Mononucleosis. J. Infect. Dis. 1985, 151, 1150-1153. [CrossRef]

39. Bu, W.; Hayes, G.M.; Liu, H.; Gemmell, L.; Schmeling, D.O.; Radecki, P.; Aguilar, F.; Burbelo, P.D.; Woo, J.; Balfour, H.H.; et al. Kinetics of Epstein-Barr Virus (EBV) Neutralizing and Virus-Specific Antibodies after Primary Infection with EBV. Clin. Vaccine Immunol. 2016, 23, 363-369. [CrossRef]

40. Henle, W.; Henle, G.; Andersson, J.; Ernberg, I.; Klein, G.; Horwitz, C.A.; Marklund, G.; Rymo, L.; Wellinder, C.; Straus, S.E. Antibody responses to Epstein-Barr virus-determined nuclear antigen (EBNA)-1 and EBNA-2 in acute and chronic Epstein-Barr virus infection. Proc. Natl. Acad. Sci. USA 1987, 84, 570-574. [CrossRef]

41. Yao, Q.Y.; Rowe, M.; Morgan, A.J.; Sam, C.K.; Prasad, U.; Dang, H.; Zeng, Y.; Rickinson, A.B. Salivary and serum IgA antibodies to the epstein-barr virus glycoprotein gp340: Incidence and potential for virus neutralization. Int. J. Cancer 2007, 48, 45-50. [CrossRef]

42. Yao, Q.Y.; Rowe, M.; Martin, B.; Young, L.; Rickinson, A.B. The Epstein-Barr virus carrier state: Dominance of a single growth-transforming isolate in the blood and in the oropharynx of healthy virus carriers. J. Gen. Virol. 1991, 72, 1579-1590. [CrossRef]

43. Fingeroth, J.D.; Weis, J.J.; Tedder, T.F.; Strominger, J.L.; Biro, P.A.; Fearon, D.T. Epstein-Barr virus receptor of human B lymphocytes is the C3d receptor CR2. Proc. Natl. Acad. Sci. USA 1984, 81, 4510-4514. [CrossRef] [PubMed]

44. Kanekiyo, M.; Bu, W.; Joyce, M.G.; Meng, G.; Whittle, J.R.; Baxa, U.; Yamamoto, T.; Narpala, S.; Todd, J.-P.; Rao, S.S.; et al. Rational Design of an Epstein-Barr Virus Vaccine Targeting the Receptor-Binding Site. Cell 2015, 162, 1090-1100. [CrossRef] [PubMed]

45. Young, K.A.; Chen, X.S.; Holers, V.M.; Hannan, J.P. Isolating the Epstein-Barr virus gp350/220 binding site on complement receptor type 2 (CR2/CD21). J. Biol. Chem. 2007, 282, 36614-36625. [CrossRef]

46. Kanda, T.; Yajima, M.; Ikuta, K. Epstein-Barr virus strain variation and cancer. Cancer Sci. 2019, 110, 1132-1139. [CrossRef] [PubMed]

47. Kelleher, C.A.; Dreyfus, D.H.; Jones, J.F.; Gelfand, E.W. EBV infection of T cells: Potential role in malignant transformation. Semin. Cancer Biol. 1996, 7, 197-207. [CrossRef]

48. Hislop, A.D.; Taylor, G.S.; Sauce, D.; Rickinson, A.B. Cellular Responses to Viral Infection in Humans: Lessons from Epstein-Barr Virus. Annu. Rev. Immunol. 2007, 25, 587-617. [CrossRef]

49. Abbott, R.J.M.; Quinn, L.L.; Leese, A.M.; Scholes, H.M.; Pachnio, A.; Rickinson, A.B. CD8+T Cell Responses to Lytic EBV Infection: Late Antigen Specificities as Subdominant Components of the Total Response. J. Immunol. 2013, 191, 5398-5409. [CrossRef]

50. Benninger-Döring, G.; Pepperl, S.; Deml, L.; Modrow, S.; Wolf, H.; Jilg, W. Frequency of CD8+ T Lymphocytes Specific for Lytic and Latent Antigens of Epstein-Barr Virus in Healthy Virus Carriers. Virology 1999, 264, 289-297. [CrossRef]

51. Saulquin, X.; Ibisch, C.; Peyrat, M.-A.; Scotet, E.; Hourmant, M.; Vie, H.; Bonneville, M.; Houssaint, E. A global appraisal of immunodominant CD8 T cell responses to Epstein-Barr virus and cytomegalovirus by bulk screening. Eur. J. Immunol. 2000, 30, 2531-2539. [CrossRef]

52. Bihl, F.; Frahm, N.; Di Giammarino, L.; Sidney, J.; John, M.; Yusim, K.; Woodberry, T.; Sango, K.; Hewitt, H.S.; Henry, L.; et al. Impact of HLA-B Alleles, Epitope Binding Affinity, Functional Avidity, and Viral Coinfection on the Immunodominance of Virus-Specific CTL Responses. J. Immunol. 2006, 176, 4094-4101. [CrossRef] [PubMed]

53. Kalra, M.; Gerdemann, U.; Luu, J.D.; Ngo, M.C.; Leen, A.M.; Louis, C.U.; Rooney, C.M.; Gottschalk, S. Epstein-Barr Virus (EBV)-derived BARF1 encodes CD4- and CD8-restricted epitopes as targets for T-cell immunotherapy. Cytotherapy 2018, 21, 212-223. [CrossRef] [PubMed]

54. Huo, S.; Luo, Y.; Deng, R.; Liu, X.; Wang, J.; Wang, L.; Zhang, B.; Wang, F.; Lu, J.; Li, X. EBV-EBNA1 constructs an immunosuppressive microenvironment for nasopharyngeal carcinoma by promoting the chemoattraction of Treg cells. J. Immunother. Cancer 2020, 8, e001588. [CrossRef] [PubMed]

55. Wilson, J.B.; Manet, E.; Gruffat, H.; Busson, P.; Blondel, M.; Fahraeus, R. EBNA1: Oncogenic Activity, Immune Evasion and Biochemical Functions Provide Targets for Novel Therapeutic Strategies against Epstein-Barr Virus- Associated Cancers. Cancers 2018, 10, 109. [CrossRef] 
56. Amyes, E.; Hatton, C.; Montamat-Sicotte, D.; Gudgeon, N.; Rickinson, A.B.; McMichael, A.J.; Callan, M.F. Characterization of the CD4+ T Cell Response to Epstein-Barr Virus during Primary and Persistent Infection. J. Exp. Med. 2003, 198, 903-911. [CrossRef]

57. Precopio, M.L.; Sullivan, J.L.; Willard, C.; Somasundaran, M.; Luzuriaga, K. Differential Kinetics and Specificity of EBV-Specific CD4+and CD8+T Cells During Primary Infection. J. Immunol. 2003, 170, 2590-2598. [CrossRef]

58. Di Trolio, R.; di Lorenzo, G.; Barbiero, E.; Iacono, A.; Franco, R.; Armiento, M.D.; Delfino, M.; Armiento, F.P.D. Expression of HECA-452 in parapsoriasis and mycosis fungoides. Int. J. Immunopathol. Pharmacol. 2006, 19, 105-110. [CrossRef]

59. Adhikary, D.; Behrends, U.; Moosmann, A.; Witter, K.; Bornkamm, G.W.; Mautner, J. Control of Epstein-Barr virus infection in vitro by $\mathrm{T}$ helper cells specific for virion glycoproteins. J. Exp. Med. 2006, 203, 995-1006. [CrossRef]

60. Wallace, L.E.; Wright, J.; Ulaeto, D.O.; Morgan, A.J.; Rickinson, A.B. Identification of two T-cell epitopes on the candidate Epstein-Barr virus vaccine glycoprotein gp340 recognized by CD4+ T-cell clones. J. Virol. 1991, 65, 3821-3828. [CrossRef]

61. Klinker, M.W.; Lizzio, V.; Reed, T.J.; Fox, D.A.; Lundy, S.K. Human B Cell-Derived Lymphoblastoid Cell Lines Constitutively Produce Fas Ligand and Secrete MHCII(+)FasL(+) Killer Exosomes. Front. Immunol. 2014, 5, 144. [CrossRef]

62. Williams, H.; McAulay, K.; Macsween, K.F.; Gallacher, N.J.; Higgins, C.D.; Harrison, N.; Swerdlow, A.; Crawford, D.H. The immune response to primary EBV infection: A role for natural killer cells. Br. J. Haematol. 2005, 129, 266-274. [CrossRef] [PubMed]

63. Dunmire, S.K.; Grimm, J.M.; Schmeling, D.O.; Balfour, H.H.; Hogquist, K.A. The Incubation Period of Primary Epstein-Barr Virus Infection: Viral Dynamics and Immunologic Events. PLoS Pathog. 2015, 11, e1005286. [CrossRef]

64. Azzi, T.; Lunemann, A.; Murer, A.; Ueda, S.; Beziat, V.; Malmberg, K.J.; Staubli, G.; Gysin, C.; Berger, C.; Munz, C.; et al. Role for early-differentiated natural killer cells in infectious mononucleosis. Blood 2014, 124, 2533-2543. [CrossRef] [PubMed]

65. Pappworth, I.Y.; Wang, E.C.; Rowe, M. The Switch from Latent to Productive Infection in Epstein-Barr Virus-Infected B Cells Is Associated with Sensitization to NK Cell Killing. J. Virol. 2007, 81, 474-482. [CrossRef]

66. Chijioke, O.; Muller, A.; Feederle, R.; Barros, M.H.; Krieg, C.; Emmel, V.; Marcenaro, E.; Leung, C.S.; Antsiferova, O.; Landtwing, V.; et al. Human natural killer cells prevent infectious mononucleosis features by targeting lytic Epstein-Barr virus infection. Cell Rep. 2013, 5, 1489-1498. [CrossRef] [PubMed]

67. Landtwing, V.; Raykova, A.; Pezzino, G.; Béziat, V.; Marcenaro, E.; Graf, C.; Moretta, A.; Capaul, R.; Zbinden, A.; Ferlazzo, G.; et al. Cognate HLA absence in trans diminishes human NK cell education. J. Clin. Investig. 2016, 126, 3772-3782. [CrossRef]

68. Abolhassani, H.; Edwards, E.S.J.; Ikinciogullari, A.; Jing, H.; Borte, S.; Buggert, M.; Du, L.; Matsuda-Lennikov, M.; Romano, R.; Caridha, R.; et al. Combined immunodeficiency and Epstein-Barr virus-induced B cell malignancy in humans with inherited CD70 deficiency. J. Exp. Med. 2016, 214, 91-106. [CrossRef]

69. Hoagland, R.J. The transmission of infectious mononucleosis. Am. J. Med. Sci. 1955, 229, 262-272. [CrossRef]

70. Balfour, H.H., Jr.; Odumade, O.A.; Schmeling, D.O.; Mullan, B.D.; Ed, J.A.; Knight, J.A.; Vezina, H.E.; Thomas, W.; Hogquist, K.A. Behavioral, virologic, and immunologic factors associated with acquisition and severity of primary Epstein-Barr virus infection in university students. J. Infect. Dis. 2013, 207, 80-88. [CrossRef] [PubMed]

71. Grimm, J.M.; Schmeling, D.O.; Dunmire, S.K.; Knight, J.A.; Mullan, B.D.; Ed, J.A.; Brundage, R.C.; Hogquist, K.A.; Balfour, H.H. Prospective studies of infectious mononucleosis in university students. Clin. Transl. Immunol. 2016, 5, e94. [CrossRef] [PubMed]

72. Crawford, D.H.; Macsween, K.F.; Higgins, C.D.; Thomas, R.; McAulay, K.; Williams, H.; Harrison, N.; Reid, S.; Conacher, M.; Douglas, J.; et al. A Cohort Study among University Students: Identification of Risk Factors for Epstein-Barr Virus Seroconversion and Infectious Mononucleosis. Clin. Infect. Dis. 2006, 43, 276-282. [CrossRef] [PubMed]

73. Shapiro, R.S.; McClain, K.; Frizzera, G.; Gajl-Peczalska, K.J.; Kersey, J.H.; Blazar, B.R.; Arthur, D.C.; Patton, D.F.; Greenberg, J.S.; Burke, B. Epstein-Barr virus associated B cell lymphoproliferative disorders following bone marrow transplantation. Blood 1988, 71, 1234-1243. [CrossRef] [PubMed]

74. Verghese, P.S.; Schmeling, D.O.; Knight, J.A.; Matas, A.J.; Balfour, H.H. Valganciclovir Administration to Kidney Donors to Reduce the Burden of Cytomegalovirus and Epstein-Barr Virus Transmission During Transplantation. Transplantation 2015, 99, 1186-1191. [CrossRef]

75. Gerber, P.; Walsh, J.; Rosenblum, E.; Purcell, R. Association of Eb-Virus Infection with the Post-Perfusion Syndrome. Lancet 1969, 293, 593-596. [CrossRef]

76. Alfieri, C.; Tanner, J.; Carpentier, L.; Perpete, C.; Savoie, A.; Paradis, K.; Delage, G.; Joncas, J. Epstein-Barr virus transmission from a blood donor to an organ transplant recipient with recovery of the same virus strain from the recipient's blood and oropharynx. Blood 1996, 87, 812-887. [CrossRef]

77. Trottier, H.; Buteau, C.; Robitaille, N.; Duval, M.; Tucci, M.; Lacroix, J.; Alfieri, C. Transfusion-related Epstein-Barr virus infection among stem cell transplant recipients: A retrospective cohort study in children. Transfusion 2012, 52, 2653-2663. [CrossRef]

78. Sumaya, C.V.; Ench, Y. Epstein-Barr Virus Infections in Families: The Role of Children with Infectious Mononucleosis. J. Infect. Dis. 1986, 154, 842-850. [CrossRef]

79. Johnson, K.H.; Webb, C.-H.; Schmeling, D.O.; Brundage, R.C.; Balfour, H.H. Epstein-Barr virus dynamics in asymptomatic immunocompetent adults: An intensive 6-month study. Clin. Transl. Immunol. 2016, 5, e81. [CrossRef]

80. Butler, L.M.; Neilands, T.B.; Mosam, A.; Mzolo, S.; Martin, J.N. A population-based study of how children are exposed to saliva in KwaZulu-Natal Province, South Africa: Implications for the spread of saliva-borne pathogens to children. Trop. Med. Int. Health 2010, 15, 442-453. [CrossRef]

81. Taylor, G.S.; Long, H.M.; Brooks, J.M.; Rickinson, A.B.; Hislop, A.D. The Immunology of Epstein-Barr Virus-Induced Disease. Annu. Rev. Immunol. 2015, 33, 787-821. [CrossRef] 
82. Sitki-Green, D.; Covington, M.; Raab-Traub, N. Compartmentalization and Transmission of Multiple Epstein-Barr Virus Strains in Asymptomatic Carriers. J. Virol. 2003, 77, 1840-1847. [CrossRef] [PubMed]

83. Walling, D.M.; Brown, A.L.; Etienne, W.; Keitel, W.A.; Ling, P.D. Multiple Epstein-Barr Virus Infections in Healthy Individuals. J. Virol. 2003, 77, 6546-6550. [CrossRef]

84. Balfour, H.H. Progress, prospects, and problems in Epstein-Barr virus vaccine development. Curr. Opin. Virol. 2014, 6, 1-5. [CrossRef] [PubMed]

85. Van Zyl, D.G.; Mautner, J.; Delecluse, H.J. Progress in EBV Vaccines. Front. Oncol. 2019, 9, 104. [CrossRef] [PubMed]

86. Black, S.; Nicolay, U.; Vesikari, T.; Knuf, M.; del Giudice, G.; Della Cioppa, G.; Tsai, T.; Clemens, R.; Rappuoli, R. Hemagglutination Inhibition Antibody Titers as a Correlate of Protection for Inactivated Influenza Vaccines in Children. Pediatr. Infect. Dis. J. 2011, 30, 1081-1085. [CrossRef] [PubMed]

87. Patel, M.; Glass, R.I.; Jiang, B.; Santosham, M.; Lopman, B.; Parashar, U. A Systematic Review of Anti-Rotavirus Serum IgA Antibody Titer as a Potential Correlate of Rotavirus Vaccine Efficacy. J. Infect. Dis. 2013, 208, 284-294. [CrossRef]

88. Ackerman, M.E.; Barouch, D.H.; Alter, G. Systems serology for evaluation of HIV vaccine trials. Immunol. Rev. 2017, 275, 262-270. [CrossRef]

89. Cortese, M.; Sherman, A.C.; Rouphael, N.G.; Pulendran, B. Systems Biological Analysis of Immune Response to Influenza Vaccination. Cold Spring Harb. Perspect. Med. 2020, 11, a038596. [CrossRef]

90. Lin, C.-L.; Lo, W.-F.; Lee, T.-H.; Ren, Y.; Hwang, S.-L.; Cheng, Y.-F.; Chen, C.-L.; Chang, Y.-S.; Lee, S.P.; Rickinson, A.B.; et al. Immunization with Epstein-Barr Virus (EBV) peptide-pulsed dendritic cells induces functional CD8+ T-cell immunity and may lead to tumor regression in patients with EBV-positive nasopharyngeal carcinoma. Cancer Res. 2002, 62, $6952-6958$.

91. Chia, W.K.; Wang, W.W.; Teo, M.; Tai, W.M.; Lim, W.T.; Tan, E.H.; Leong, S.S.; Sun, L.; Chen, J.J.; Gottschalk, S.; et al. A phase II study evaluating the safety and efficacy of an adenovirus-DeltaLMP1-LMP2 transduced dendritic cell vaccine in patients with advanced metastatic nasopharyngeal carcinoma. Ann. Oncol. 2012, 23, 997-1005. [CrossRef]

92. Hui, E.P.; Taylor, G.S.; Jia, H.; Ma, B.; Chan, S.; Ho, R.; Wong, W.-L.; Wilson, S.; Johnson, B.; Edwards, C.; et al. Phase I Trial of Recombinant Modified Vaccinia Ankara Encoding Epstein-Barr Viral Tumor Antigens in Nasopharyngeal Carcinoma Patients. Cancer Res. 2013, 73, 1676-1688. [CrossRef] [PubMed]

93. Taylor, G.S.; Jia, H.; Harrington, K.; Lee, L.W.; Turner, J.; Ladell, K.; Price, D.; Tanday, M.; Matthews, J.; Roberts, C.; et al. A Recombinant Modified Vaccinia Ankara Vaccine Encoding Epstein-Barr Virus (EBV) Target Antigens: A Phase I Trial in UK Patients with EBV-Positive Cancer. Clin. Cancer Res. 2014, 20, 5009-5022. [CrossRef] [PubMed]

94. Tashiro, H.; Brenner, M.K. Immunotherapy against cancer-related viruses. Cell Res. 2016, 27, 59-73. [CrossRef]

95. Si, Y.; Deng, Z.; Lan, G.; Du, H.; Wang, Y.; Si, J.; Wei, J.; Weng, J.; Qin, Y.; Huang, B.; et al. The Safety and Immunological Effects of rAd5-EBV-LMP2 Vaccine in Nasopharyngeal Carcinoma Patients: A Phase I Clinical Trial and Two-Year Follow-Up. Chem. Pharm. Bull. 2016, 64, 1118-1123. [CrossRef] [PubMed]

96. Hagn, M.; Panikkar, A.; Smith, C.; Balfour, H.H., Jr.; Khanna, R.; Voskoboinik, I.; Trapani, J.A. B cell-derived circulating granzyme $\mathrm{B}$ is a feature of acute infectious mononucleosis. Clin. Transl. Immunol. 2015, 4, e38. [CrossRef]

97. Burrows, S.R.; Moss, D.J.; Khanna, R. Understanding human T-cell-mediated immunoregulation through herpesviruses. Immunol. Cell Biol. 2011, 89, 352-358. [CrossRef] [PubMed]

98. Panikkar, A.; Smith, C.; Hislop, A.D.; Tellam, N.; Dasari, V.; Hogquist, K.A.; Wykes, M.; Moss, D.J.; Rickinson, A.; Balfour, H.H.; et al. Impaired Epstein-Barr Virus-Specific Neutralizing Antibody Response during Acute Infectious Mononucleosis Is Coincident with Global B-Cell Dysfunction. J. Virol. 2015, 89, 9137-9141. [CrossRef]

99. Panikkar, A.; Smith, C.; Hislop, A.; Tellam, N.; Dasari, V.; Hogquist, K.A.; Wykes, M.; Moss, D.J.; Rickinson, A.; Balfour, H.H., Jr.; et al. Cytokine-Mediated Loss of Blood Dendritic Cells During Epstein-Barr Virus-Associated Acute Infectious Mononucleosis: Implication for Immune Dysregulation. J. Infect. Dis. 2015, 212, 1957-1961. [CrossRef]

100. Morgan, A.J.; Epstein, M.A.; North, J.R. Comparative immunogenicity studies on epstein-barr virus membrane antigen (MA) gp340 with novel adjuvants in mice, rabbits, and cotton-top tamarins. J. Med. Virol. 1984, 13, 281-292. [CrossRef]

101. Morgan, A.J.; Finerty, S.; Lovgren, K.; Scullion, F.T.; Morein, B. Prevention of Epstein-Barr (EB) Virus-induced Lymphoma in Cottontop Tamarins by Vaccination with the EB Virus Envelope Glycoprotein gp340 Incorporated into Immune-stimulating Complexes. J. Gen. Virol. 1988, 69, 2093-2096. [CrossRef]

102. Finerty, S.; Tarlton, J.; Mackett, M.; Conway, M.; Arrand, J.R.; Watkins, P.E.; Morgan, A.J. Protective immunization against Epstein-Barr virus-induced disease in cottontop tamarins using the virus envelope glycoprotein gp340 produced from a bovine papillomavirus expression vector. J. Gen. Virol. 1992, 73, 449-453. [CrossRef] [PubMed]

103. Finerty, S.; Mackett, M.; Arrand, J.R.; Watkins, P.E.; Tarlton, J.; Morgan, A.J. Immunization of cottontop tamarins and rabbits with a candidate vaccine against the Epstein-Barr virus based on the major viral envelope glycoprotein gp340 and alum. Vaccine 1994, 12, 1180-1184. [CrossRef]

104. Klasse, P.J.; Nixon, D.F.; Moore, J.P. Immunogenicity of clinically relevant SARS-CoV-2 vaccines in nonhuman primates and humans. Sci. Adv. 2021, 7, eabe8065. [CrossRef]

105. Moutschen, M.; Léonard, P.; Sokal, E.; Smets, F.; Haumont, M.; Mazzu, P.; Bollen, A.; Denamur, F.; Peeters, P.; Dubin, G.; et al. Phase I/II studies to evaluate safety and immunogenicity of a recombinant gp350 Epstein-Barr virus vaccine in healthy adults. Vaccine 2007, 25, 4697-4705. [CrossRef] [PubMed] 
106. Epstein, M.A.; Morgan, A.J.; Finerty, S.; Randle, B.J.; Kirkwood, J.K. Protection of cottontop tamarins against Epstein-Barr virus-induced malignant lymphoma by a prototype subunit vaccine. Nature 1985, 318, 287-289. [CrossRef] [PubMed]

107. Emini, E.A.; Schleif, W.A.; Silberklang, M.; Lehman, D.; Ellis, R.W. Vero cell-expressed Epstein-Barr virus (EBV) gp350/220 protects marmosets from EBV challenge. J. Med. Virol. 1989, 27, 120-123. [CrossRef]

108. Leskowitz, R.; Fogg, M.H.; Zhou, X.Y.; Kaur, A.; Silveira, E.L.V.; Villinger, F.; Lieberman, P.M.; Wang, F.; Ertl, H.C. AdenovirusBased Vaccines against Rhesus Lymphocryptovirus EBNA-1 Induce Expansion of Specific CD8+ and CD4+ T Cells in Persistently Infected Rhesus Macaques. J. Virol. 2014, 88, 4721-4735. [CrossRef]

109. Leskowitz, R.M.; Zhou, X.Y.; Villinger, F.; Fogg, M.H.; Kaur, A.; Lieberman, P.M.; Wang, F.; Ertl, H.C. CD4 + and CD8 + T-Cell Responses to Latent Antigen EBNA-1 and Lytic Antigen BZLF-1 during Persistent Lymphocryptovirus Infection of Rhesus Macaques. J. Virol. 2013, 87, 8351-8362. [CrossRef]

110. Rivailler, P.; Carville, A.; Kaur, A.; Rao, P.; Quink, C.; Kutok, J.L.; Westmoreland, S.; Klumpp, S.; Simon, M.; Aster, J.C.; et al. Experimental rhesus lymphocryptovirus infection in immunosuppressed macaques: An animal model for Epstein-Barr virus pathogenesis in the immunosuppressed host. Blood 2004, 104, 1482-1489. [CrossRef]

111. Moghaddam, A.; Koch, J.; Annis, B.; Wang, F. Infection of human B lymphocytes with lymphocryptoviruses related to Epstein-Barr virus. J. Virol. 1998, 72, 3205-3212. [CrossRef]

112. Sestak, K. Non-Human Primate Models of Enteric Viral Infections. Viruses 2018, 10, 544. [CrossRef]

113. Sashihara, J.; Hoshino, Y.; Bowman, J.J.; Krogmann, T.; Burbelo, P.D.; Coffield, V.M.; Kamrud, K.; Cohen, J.I. Soluble Rhesus Lymphocryptovirus gp350 Protects against Infection and Reduces Viral Loads in Animals that Become Infected with Virus after Challenge. PLoS Pathog. 2011, 7, e1002308. [CrossRef] [PubMed]

114. Heeke, D.S.; Lin, R.; Rao, E.; Woo, J.C.; McCarthy, M.P.; Marshall, J.D. Identification of GLA/SE as an effective adjuvant for the induction of robust humoral and cell-mediated immune responses to EBV-gp350 in mice and rabbits. Vaccine 2016, 34, 2562-2569. [CrossRef]

115. Singh, S.; Homad, L.J.; Akins, N.R.; Stoffers, C.M.; Lackhar, S.; Malhi, H.; Wan, Y.-H.; Rawlings, D.J.; McGuire, A.T. Neutralizing Antibodies Protect against Oral Transmission of Lymphocryptovirus. Cell Rep. Med. 2020, 1, 100033. [CrossRef] [PubMed]

116. Takashima, K.; Ohashi, M.; Kitamura, Y.; Ando, K.; Nagashima, K.; Sugihara, H.; Okuno, K.; Sairenji, T.; Hayashi, K. A new animal model for primary and persistent Epstein-Barr virus infection: Human EBV-infected rabbit characteristics determined using sequential imaging and pathological analysis. J. Med. Virol. 2008, 80, 455-466. [CrossRef] [PubMed]

117. Kanai, K.; Takashima, K.; Okuno, K.; Kato, K.; Sano, H.; Kuwamoto, S.; Higaki, H.; Nagata, K.; Sugihara, H.; Kato, M.; et al. Lifelong persistent EBV infection of rabbits with EBER1-positive lymphocyte infiltration and mild sublethal hemophagocytosis Virus Res. 2010, 153, 172-178. [CrossRef] [PubMed]

118. Wang, Z.; Yang, S.; Zhou, L.; Du, H.; Mo, W.; Zeng, Y. Specific cellular immune responses in mice immunized with DNA, adeno-associated virus and adenoviral vaccines of Epstein-Barr virus-LMP2 alone or in combination. Sci. China Life Sci. 2011, 54, 263-266. [CrossRef] [PubMed]

119. Cui, X.; Cao, Z.; Sen, G.; Chattopadhyay, G.; Fuller, D.H.; Fuller, J.T.; Snapper, D.M.; Snow, A.L.; Mond, J.J.; Snapper, C.M. A novel tetrameric gp350 1-470 as a potential Epstein-Barr virus vaccine. Vaccine 2013, 31, 3039-3045. [CrossRef] [PubMed]

120. Wang, M.; Jiang, S.; Liu, X.; Wang, Y. Expression, purification, and immunogenic characterization of Epstein-Barr virus recombinant EBNA1 protein in Pichia pastoris. Appl. Microbiol. Biotechnol. 2013, 97, 6251-6262. [CrossRef] [PubMed]

121. Bharadwaj, M.; Sherritt, M.; Khanna, R.; Moss, D. Contrasting Epstein-Barr virus-specific cytotoxic T cell responses to HLA A2-restricted epitopes in humans and HLA transgenic mice: Implications for vaccine design. Vaccine 2001, 19, 3769-3777. [CrossRef]

122. Hartlage, A.S.; Liu, T.; Patton, J.T.; Garman, S.L.; Zhang, X.; Kurt, H.; Lozanski, G.; Lustberg, M.E.; Caligiuri, M.A.; Baiocchi, R.A. The Epstein-Barr Virus Lytic Protein BZLF1 as a Candidate Target Antigen for Vaccine Development. Cancer Immunol. Res. 2015, 3, 787-794. [CrossRef]

123. Van Zyl, D.G.; Tsai, M.H.; Shumilov, A.; Schneidt, V.; Poirey, R.; Schlehe, B.; Fluhr, H.; Mautner, J.; Delecluse, H.-J. Immunogenic particles with a broad antigenic spectrum stimulate cytolytic $\mathrm{T}$ cells and offer increased protection against EBV infection ex vivo and in mice. PLoS Pathog. 2018, 14, e1007464. [CrossRef] [PubMed]

124. Traggiai, E.; Chicha, L.; Mazzucchelli, L.; Bronz, L.; Piffaretti, J.-C.; Lanzavecchia, A.; Manz, M.G. Development of a Human Adaptive Immune System in Cord Blood Cell-Transplanted Mice. Science 2004, 304, 104-107. [CrossRef] [PubMed]

125. Elliott, S.L.; Suhrbier, A.; Miles, J.J.; Lawrence, G.; Pye, S.J.; Le, T.T.; Rosenstengel, A.; Nguyen, T.; Allworth, A.; Burrows, S.; et al. Phase I Trial of a CD8 + T-Cell Peptide Epitope-Based Vaccine for Infectious Mononucleosis. J. Virol. 2008, 82, $1448-1457$. [CrossRef] [PubMed]

126. Chesnokova, L.S.; Hutt-Fletcher, L.M. Fusion of Epstein-Barr virus with epithelial cells can be triggered by alphavbeta5 in addition to alphavbeta6 and alphavbeta8, and integrin binding triggers a conformational change in glycoproteins gHgL. J. Virol. 2011, 85, 13214-13223. [CrossRef]

127. Li, Q.; Turk, S.M.; Hutt-Fletcher, L.M. The Epstein-Barr virus (EBV) BZLF2 gene product associates with the gH and gL homologs of EBV and carries an epitope critical to infection of B cells but not of epithelial cells. J. Virol. 1995, 69, 3987-3994. [CrossRef]

128. Turk, S.M.; Jiang, R.; Chesnokova, L.S.; Hutt-Fletcher, L.M. Antibodies to gp350/220 enhance the ability of Epstein-Barr virus to infect epithelial cells. J. Virol. 2006, 80, 9628-9633. [CrossRef] 
129. Snijder, J.; Ortego, M.S.; Weidle, C.; Stuart, A.B.; Gray, M.D.; McElrath, M.J.; Pancera, M.; Veesler, D.; McGuire, A.T. An Antibody Targeting the Fusion Machinery Neutralizes Dual-Tropic Infection and Defines a Site of Vulnerability on Epstein-Barr Virus. Immunity 2018, 48, 799-811. [CrossRef]

130. Coleman, C.; Wohlford, E.M.; Smith, N.A.; King, C.A.; Ritchie, J.A.; Baresel, P.C.; Kimura, H.; Rochford, R. Epstein-Barr Virus Type 2 Latently Infects T Cells, Inducing an Atypical Activation Characterized by Expression of Lymphotactic Cytokines. J. Virol. 2014, 89, 2301-2312. [CrossRef]

131. Coleman, C.B.; Daud, I.I.; Ogolla, S.O.; Ritchie, J.A.; Smith, N.A.; Sumba, P.O.; Dent, A.E.; Rochford, R. Epstein-Barr Virus Type 2 Infects T Cells in Healthy Kenyan Children. J. Infect. Dis. 2017, 216, 670-677. [CrossRef]

132. Isobe, Y.; Sugimoto, K.; Yang, L.; Tamayose, K.; Egashira, M.; Kaneko, T.; Takada, K.; Oshimi, K. Epstein-Barr virus infection of human natural killer cell lines and peripheral blood natural killer cells. Cancer Res. 2004, 64, 2167-2174. [CrossRef]

133. Brooks, J.M.; Long, H.M.; Tierney, R.J.; Shannon-Lowe, C.; Leese, A.M.; Fitzpatrick, M.; Taylor, G.S.; Rickinson, A.B. Early T Cell Recognition of B Cells following Epstein-Barr Virus Infection: Identifying Potential Targets for Prophylactic Vaccination. PLoS Pathog. 2016, 12, e1005549. [CrossRef] [PubMed]

134. Pavlova, S.; Feederle, R.; Gärtner, K.; Fuchs, W.; Granzow, H.; Delecluse, H.-J. An Epstein-Barr Virus Mutant Produces Immunogenic Defective Particles Devoid of Viral DNA. J. Virol. 2012, 87, 2011-2022. [CrossRef] [PubMed]

135. Adhikary, D.; Behrends, U.; Feederle, R.; Delecluse, H.-J.; Mautner, J. Standardized and Highly Efficient Expansion of Epstein-Barr Virus-Specific CD4 + T Cells by Using Virus-Like Particles. J. Virol. 2008, 82, 3903-3911. [CrossRef] [PubMed]

136. Bollard, C.M.; Gottschalk, S.; Torrano, V.; Diouf, O.; Ku, S.; Hazrat, Y.; Carrum, G.; Ramos, C.; Fayad, L.; Shpall, E.J.; et al. Sustained Complete Responses in Patients with Lymphoma Receiving Autologous Cytotoxic T Lymphocytes Targeting Epstein-Barr Virus Latent Membrane Proteins. J. Clin. Oncol. 2014, 32, 798-808. [CrossRef] [PubMed]

137. Gottschalk, S.; Rooney, C.M. Adoptive T-Cell Immunotherapy. Curr. Top. Microbiol. Immunol. 2015, 391, 427-454. [CrossRef]

138. Bollard, C.M.; Tripic, T.; Cruz, C.R.; Dotti, G.; Gottschalk, S.; Torrano, V.; Dakhova, O.; Carrum, G.; Ramos, C.A.; Liu, H.; et al. Tumor-Specific T-Cells Engineered to Overcome Tumor Immune Evasion Induce Clinical Responses in Patients with Relapsed Hodgkin Lymphoma. J. Clin. Oncol. 2018, 36, 1128-1139. [CrossRef]

139. Bencun, M.; Klinke, O.; Hotz-Wagenblatt, A.; Klaus, S.; Tsai, M.-H.; Poirey, R.; Delecluse, H.-J. Translational profiling of B cells infected with the Epstein-Barr virus reveals $5^{\prime}$ leader ribosome recruitment through upstream open reading frames. Nucleic Acids Res. 2018, 46, 2802-2819. [CrossRef]

140. Bogedain, C.; Wolf, H.; Modrow, S.; Stuber, G.; Jilg, W. Specific cytotoxic T lymphocytes recognize the immediate-early transactivator Zta of Epstein-Barr virus. J. Virol. 1995, 69, 4872-4879. [CrossRef]

141. Woodberry, T.; Suscovich, T.J.; Henry, L.M.; Davis, J.K.; Frahm, N.; Walker, B.D.; Scadden, D.T.; Wang, F.; Brander, C. Differential Targeting and Shifts in the Immunodominance of Epstein-Barr Virus-Specific CD8 and CD4 T Cell Responses during Acute and Persistent Infection. J. Infect. Dis. 2005, 192, 1513-1524. [CrossRef]

142. Jondal, M. Antibody-dependent cellular cytotoxicity (ADCC) against Epstein-Barr virus-determined membrane antigens. I. Reactivity in sera from normal persons and from patients with acute infectious mononucleosis. Clin. Exp. Immunol. 1976, 25, 1-5. [PubMed]

143. Strnad, B.C.; Schuster, T.; Klein, R.; Hopkins, R.F., 3rd; Witmer, T.; Neubauer, R.H.; Rabin, H. Production and characterization of monoclonal antibodies against the Epstein-Barr virus membrane antigen. J. Virol. 1982, 41, 258-264. [CrossRef]

144. Khyatti, M.; Patel, P.C.; Stefanescu, I.; Menezes, J. Epstein-Barr virus (EBV) glycoprotein gp350 expressed on transfected cells resistant to natural killer cell activity serves as a target antigen for EBV-specific antibody-dependent cellular cytotoxicity. J. Virol. 1991, 65, 996-1001. [CrossRef] [PubMed]

145. López-Montañés, M.; Alari-Pahissa, E.; Sintes, J.; Rodriguez, J.E.M.; Muntasell, A.; López-Botet, M. Antibody-Dependent NK Cell Activation Differentially Targets EBV-Infected Cells in Lytic Cycle and Bystander B Lymphocytes Bound to Viral Antigen-Containing Particles. J. Immunol. 2017, 199, 656-665. [CrossRef] [PubMed]

146. Hambleton, S.; Steinberg, S.P.; LaRussa, P.S.; Shapiro, E.D.; Gershon, A.A. Risk of Herpes Zoster in Adults Immunized with Varicella Vaccine. J. Infect. Dis. 2008, 197 (Suppl. S2), S196-S199. [CrossRef]

147. Tugizov, S.M.; Berline, J.W.; Palefsky, J.M. Epstein-Barr virus infection of polarized tongue and nasopharyngeal epithelial cells. Nat. Med. 2003, 9, 307-314. [CrossRef]

148. Xiao, J.; Palefsky, J.M.; Herrera, R.; Berline, J.; Tugizov, S.M. EBV BMRF-2 facilitates cell-to-cell spread of virus within polarized oral epithelial cells. Virology 2009, 388, 335-343. [CrossRef]

149. Ohga, S.; Nomura, A.; Takada, H.; Hara, T. Immunological aspects of Epstein-Barr virus infection. Crit. Rev. Oncol. Hematol. 2002, 44, 203-215. [CrossRef]

150. Ogembo, J.; Kannan, L.; Ghiran, I.; Nicholson-Weller, A.; Finberg, R.W.; Tsokos, G.C.; Fingeroth, J.D. Human Complement Receptor Type 1/CD35 Is an Epstein-Barr Virus Receptor. Cell Rep. 2013, 3, 371-385. [CrossRef]

151. Sathiyamoorthy, K.; Hu, Y.X.; Möhl, B.S.; Chen, J.; Longnecker, R.; Jardetzky, T.S. Structural basis for Epstein-Barr virus host cell tropism mediated by gp42 and gHgL entry glycoproteins. Nat. Commun. 2016, 7, 13557. [CrossRef]

152. Sathiyamoorthy, K.; Jiang, J.; Hu, Y.X.; Rowe, C.L.; Möhl, B.S.; Chen, J.; Jiang, W.; Mellins, E.D.; Longnecker, R.; Zhou, Z.H.; et al. Assembly and Architecture of the EBV B Cell Entry Triggering Complex. PLoS Pathog. 2014, 10, e1004309. [CrossRef]

153. Qualtiere, L.F.; Chase, R.; Pearson, G.R. Purification and biologic characterization of a major Epstein Barr virus-induced membrane glycoprotein. J. Immunol. 1982, 129, 814-818. [PubMed] 
154. Khanna, R.; Sherritt, M.; Burrows, S.R. EBV structural antigens, gp350 and gp85, as targets for ex vivo virus-specific CTL during acute infectious mononucleosis: Potential use of gp350/gp85 CTL epitopes for vaccine design. J. Immunol. 1999, 162, 3063-3069. [PubMed]

155. Sokal, E.M.; Hoppenbrouwers, K.; Vandermeulen, C.; Moutschen, M.; Leonard, P.; Moreels, A.; Haumont, M.; Bollen, A.; Smets, F.; Denis, M. Recombinant gp350 vaccine for infectious mononucleosis: A phase 2, randomized, double-blind, placebo-controlled trial to evaluate the safety, immunogenicity, and efficacy of an Epstein-Barr virus vaccine in healthy young adults. J. Infect. Dis. 2007, 196, 1749-1753. [CrossRef] [PubMed]

156. Hettich, E.; Janz, A.; Zeidler, R.; Pich, D.; Hellebrand, E.; Weissflog, B.; Moosmann, A.; Hammerschmidt, W. Genetic design of an optimized packaging cell line for gene vectors transducing human B cells. Gene Ther. 2006, 13, 844-856. [CrossRef] [PubMed]

157. Granato, M.; Feederle, R.; Farina, A.; Gonnella, R.; Santarelli, R.; Hub, B.; Faggioni, A.; Delecluse, H.-J. Deletion of Epstein-Barr Virus BFLF2 Leads to Impaired Viral DNA Packaging and Primary Egress as Well as to the Production of Defective Viral Particles. J. Virol. 2008, 82, 4042-4051. [CrossRef] [PubMed]

158. Tanner, J.E.; Hu, J.; Alfieri, C. Construction and Characterization of a Humanized Anti-Epstein-Barr Virus gp350 Antibody with Neutralizing Activity in Cell Culture. Cancers 2018, 10, 112. [CrossRef]

159. Tosoni-Pittoni, E.; Joab, I.; Nicolas, J.C.; Perricaudet, M. Complete characterization of the gene coding for the Epstein-Barr virus major membrane antigen gp 220/340 and selective expression of a secreted form of gp 220. Biochem. Biophys. Res. Commun. 1989, 158, 676-684. [CrossRef]

160. Cui, X.; Cao, Z.; Chen, Q.; Arjunaraja, S.; Snow, A.; Snapper, C.M. Rabbits immunized with Epstein-Barr virus gH/gL or gB recombinant proteins elicit higher serum virus neutralizing activity than gp350. Vaccine 2016, 34, 4050-4055. [CrossRef]

161. Bu, W.; Joyce, M.G.; Nguyen, H.; Banh, D.; Aguilar, F.; Tariq, Z.; Yap, M.L.; Tsujimura, Y.; Gillespie, R.A.; Tsybovsky, Y.; et al. Immunization with Components of the Viral Fusion Apparatus Elicits Antibodies That Neutralize Epstein-Barr Virus in B Cells and Epithelial Cells. Immunity 2019, 50, 1305-1316.e6. [CrossRef]

162. Escalante, G.M.; Foley, J.; Mutsvunguma, L.Z.; Rodriguez, E.; Mulama, D.H.; Muniraju, M.; Ye, P.; Barasa, A.K.; Ogembo, J.G. A Pentavalent Epstein-Barr Virus-Like Particle Vaccine Elicits High Titers of Neutralizing Antibodies against Epstein-Barr Virus Infection in Immunized Rabbits. Vaccines 2020, 8, 169. [CrossRef] [PubMed]

163. Pearson, G.; Dewey, F.; Klein, G.; Henle, G. Relation Between Neutralization of Epstein-Barr Virus and Antibodies to CellMembrane Antigens Induced by the Virus2. J. Natl. Cancer Inst. 1970, 45, 989-995. [CrossRef] [PubMed]

164. Mackett, M.; Arrand, J.R. Recombinant vaccinia virus induces neutralising antibodies in rabbits against Epstein-Barr virus membrane antigen gp340. EMBO J. 1985, 4, 3229-3234. [CrossRef] [PubMed]

165. Epstein, M.A.; Randle, B.J.; Finerty, S.; Kirkwood, J.K. Not all potently neutralizing, vaccine-induced antibodies to Epstein-Barr virus ensure protection of susceptible experimental animals. Clin. Exp. Immunol. 1986, 63, 485-490.

166. Morgan, A.J.; Mackett, M.; Finerty, S.; Arrand, J.R.; Scullion, F.T.; Epstein, M.A. Recombinant vaccinia virus expressing epsteinbarr virus glycoprotein gp340 protects cottontop tamarins against EB virus-induced malignant lymphomas. J. Med. Virol. 1988, 25, 189-195. [CrossRef] [PubMed]

167. Jackman, W.T.; Mann, K.A.; Hoffmann, H.J.; Spaete, R.R. Expression of Epstein-Barr virus gp350 as a single chain glycoprotein for an EBV subunit vaccine. Vaccine 1999, 17, 660-668. [CrossRef]

168. Servat, E.; Ro, B.W.; Cayatte, C.; Gemmell, L.; Barton, C.; Rao, E.; Lin, R.; Zuo, F.; Woo, J.C.; Hayes, G.M. Identification of the critical attribute(s) of EBV gp350 antigen required for elicitation of a neutralizing antibody response in vivo. Vaccine 2015, 33, 6771-6777. [CrossRef] [PubMed]

169. Gu, S.Y.; Huang, T.M.; Ruan, L.; Miao, Y.H.; Lu, H.; Chu, C.M.; Motz, M.; Wolf, H. First EBV vaccine trial in humans using recombinant vaccinia virus expressing the major membrane antigen. Dev. Biol. Stand. 1995, 84, 171-177.

170. Casey, C.G.; Iskander, J.K.; Roper, M.H.; Mast, E.E.; Wen, X.J.; Torok, T.J.; Chapman, L.E.; Swerdlow, D.L.; Morgan, J.; Heffelfinger, J.D.; et al. Adverse events associated with smallpox vaccination in the United States, January-October 2003. JAMA 2005, 294, 2734-2743. [CrossRef]

171. Rees, L.; Tizard, E.J.; Morgan, A.J.; Cubitt, W.D.; Finerty, S.; Oyewole-Eletu, T.A.; Owen, K.; Royed, C.; Stevens, S.J.; Shroff, R.C.; et al. A Phase I Trial of Epstein-Barr Virus Gp350 Vaccine for Children with Chronic Kidney Disease Awaiting Transplantation. Transplantation 2009, 88, 1025-1029. [CrossRef]

172. Nemerow, G.R.; Houghten, R.A.; Moore, M.D.; Cooper, N.R. Identification of an epitope in the major envelope protein of Epstein-Barr virus that mediates viral binding to the B lymphocyte EBV receptor (CR2). Cell 1989, 56, 369-377. [CrossRef]

173. Hoffman, G.J.; Lazarowitz, S.G.; Hayward, S.D. Monoclonal antibody against a 250,000-dalton glycoprotein of Epstein-Barr virus identifies a membrane antigen and a neutralizing antigen. Proc. Natl. Acad. Sci. USA 1980, 77, 2979-2983. [CrossRef]

174. Tanner, J.E.; Coinçon, M.; Leblond, V.; Hu, J.; Fang, J.M.; Sygusch, J.; Alfieri, C. Peptides Designed to Spatially Depict the Epstein-Barr Virus Major Virion Glycoprotein gp350 Neutralization Epitope Elicit Antibodies That Block Virus-Neutralizing Antibody 72A1 Interaction with the Native gp350 Molecule. J. Virol. 2015, 89, 4932-4941. [CrossRef] [PubMed]

175. Liu, H.; Chen, H.; Liu, Z.; Le, Z.; Nie, T.; Qiao, D.; Su, Y.; Mai, H.; Chen, Y.; Liu, L. Therapeutic nanovaccines sensitize EBV-associated tumors to checkpoint blockade therapy. Biomaterials 2020, 255, 120158. [CrossRef] [PubMed]

176. Kim, Y.; Kang, S.; Shin, H.; Kim, T.; Yu, B.; Kim, J.; Yoo, D.; Jon, S. Sequential and Timely Combination of a Cancer Nanovaccine with Immune Checkpoint Blockade Effectively Inhibits Tumor Growth and Relapse. Angew. Chem. Int. Ed. 2020, 59, 14628-14638. [CrossRef] [PubMed] 
177. Khanna, R.; Burrows, S.R.; Kurilla, M.G.; Jacob, C.A.; Misko, I.S.; Sculley, T.B.; Kieff, E.; Moss, D.J. Localization of Epstein-Barr virus cytotoxic T cell epitopes using recombinant vaccinia: Implications for vaccine development. J. Exp. Med. 1992, 176, 169-176. [CrossRef] [PubMed]

178. Burrows, S.R.; Sculley, T.B.; Misko, I.S.; Schmidt, C.; Moss, D.J. An Epstein-Barr virus-specific cytotoxic T cell epitope in EBV nuclear antigen 3 (EBNA 3). J. Exp. Med. 1990, 171, 345-349. [CrossRef] [PubMed]

179. Murray, R.J.; Kurilla, M.G.; Brooks, J.M.; Thomas, W.A.; Rowe, M.; Kieff, E.; Rickinson, A.B. Identification of target antigens for the human cytotoxic T cell response to Epstein-Barr virus (EBV): Implications for the immune control of EBV-positive malignancies. J. Exp. Med. 1992, 176, 157-168. [CrossRef] [PubMed]

180. Khanna, R.; Burrows, S.R.; Neisig, A.; Neefjes, J.; Moss, D.J.; Silins, S.L. Hierarchy of Epstein-Barr virus-specific cytotoxic T-cell responses in individuals carrying different subtypes of an HLA allele: Implications for epitope-based antiviral vaccines. J. Virol. 1997, 71, 7429-7435. [CrossRef]

181. Rickinson, A.B.; Moss, D.J. Human Cytotoxic T Lymphocyte Responses to Epstein-Barr Virus Infection. Annu. Rev. Immunol. 1997, 15, 405-431. [CrossRef]

182. Tellam, J.; Connolly, G.; Green, K.J.; Miles, J.; Moss, D.J.; Burrows, S.R.; Khanna, R. Endogenous Presentation of CD8+ T Cell Epitopes from Epstein-Barr Virus-encoded Nuclear Antigen 1. J. Exp. Med. 2004, 199, 1421-1431. [CrossRef] [PubMed]

183. Duraiswamy, J.; Sherritt, M.; Thomson, S.; Tellam, J.; Cooper, L.; Connolly, G.; Bharadwaj, M.; Khanna, R. Therapeutic LMP1 polyepitope vaccine for EBV-associated Hodgkin disease and nasopharyngeal carcinoma. Blood 2003, 101, 3150-3156. [CrossRef] [PubMed]

184. Liu, G.; Yao, K.; Wang, B.; Chen, Y.; Zhou, F.; Guo, Y.; Xu, J.; Shi, H. Immunotherapy of Epstein-Barr Virus Associated Malignancies Using Mycobacterial HSP70 and LMP2A356-364 Epitope Fusion Protein. Cell. Mol. Immunol. 2009, 6, 423-431. [CrossRef] [PubMed]

185. Pan, J.; Zhang, Q.; Zhou, J.; Ma, D.; Xiao, X.; Wang, D.W. Recombinant adeno-associated virus encoding Epstein-Barr virus latent membrane proteins fused with heat shock protein as a potential vaccine for nasopharyngeal carcinoma. Mol. Cancer Ther. 2009, 8 , 2754-2761. [CrossRef] [PubMed]

186. Lin, X.; Chen, S.; Xue, X.; Lu, L.; Zhu, S.; Li, W.; Chen, X.; Zhong, X.; Jiang, P.; Sename, T.S.; et al. Chimerically fused antigen rich of overlapped epitopes from latent membrane protein 2 (LMP2) of Epstein-Barr virus as a potential vaccine and diagnostic agent. Cell. Mol. Immunol. 2015, 13, 492-501. [CrossRef]

187. Liu, G.; Yao, K.; Wang, B.; Zhou, F.; Chen, Y.; Li, L.; Chi, J.; Peng, G. Reconstituted complexes of mycobacterial HSP70 and EBV LMP2A-derived peptides elicit peptide-specific cytotoxic T lymphocyte responses and anti-tumor immunity. Vaccine 2011, 29, 7414-7423. [CrossRef]

188. Silveira, E.; Fogg, M.H.; Leskowitz, R.M.; Ertl, H.C.; Wiseman, R.W.; O'Connor, D.; Lieberman, P.; Wang, F.; Villinger, F. Therapeutic Vaccination against the Rhesus Lymphocryptovirus EBNA-1 Homologue, rhEBNA-1, Elicits T Cell Responses to Novel Epitopes in Rhesus Macaques. J. Virol. 2013, 87, 13904-13910. [CrossRef]

189. Ogembo, J.G.; Muraswki, M.R.; McGinnes, L.W.; Parcharidou, A.; Sutiwisesak, R.; Tison, T.; Avendano, J.; Agnani, D.; Finberg, R.W.; Morrison, T.G.; et al. A chimeric EBV gp350/220-based VLP replicates the virion B-cell attachment mechanism and elicits long-lasting neutralizing antibodies in mice. J. Transl. Med. 2015, 13, 50. [CrossRef]

190. Li, F.; Song, D.; Lu, Y.; Zhu, H.; Chen, Z.; He, X. Delayed-type Hypersensitivity (DTH) Immune Response Related With EBV-DNA in Nasopharyngeal Carcinoma Treated with Autologous Dendritic Cell Vaccination After Radiotherapy. J. Immunother. 2013, 36, 208-214. [CrossRef]

191. Ewer, K.J.; Lambe, T.; Rollier, C.S.; Spencer, A.; Hill, A.; Dorrell, L. Viral vectors as vaccine platforms: From immunogenicity to impact. Curr. Opin. Immunol. 2016, 41, 47-54. [CrossRef]

192. Small, J.C.; Ertl, H.C. Viruses-From pathogens to vaccine carriers. Curr. Opin. Virol. 2011, 1, 241-245. [CrossRef] [PubMed]

193. Ura, T.; Okuda, K.; Shimada, M. Developments in Viral Vector-Based Vaccines. Vaccines 2014, 2, 624-641. [CrossRef] [PubMed]

194. Sánchez-Sampedro, L.; Perdiguero, B.; Mejías-Pérez, E.; García-Arriaza, J.; di Pilato, M.; Esteban, M. The Evolution of Poxvirus Vaccines. Viruses 2015, 7, 1726-1803. [CrossRef]

195. Parrino, J.; McCurdy, L.H.; Larkin, B.D.; Gordon, I.J.; Rucker, S.E.; Enama, M.E.; Koup, R.A.; Roederer, M.; Bailer, R.T.; Moodie, Z.; et al. Safety, immunogenicity and efficacy of modified vaccinia Ankara (MVA) against Dryvax ${ }^{\circledR}$ challenge in vaccinia-naïve and vaccinia-immune individuals. Vaccine 2006, 25, 1513-1525. [CrossRef] [PubMed]

196. Smith, C.; Tsang, J.; Beagley, L.; Chua, D.; Lee, V.; Li, V.; Moss, D.J.; Coman, W.; Chan, K.H.; Nicholls, J.M.; et al. Effective Treatment of Metastatic Forms of Epstein-Barr Virus-Associated Nasopharyngeal Carcinoma with a Novel Adenovirus-Based Adoptive Immunotherapy. Cancer Res. 2012, 72, 1116-1125. [CrossRef] [PubMed]

197. Zimmermann, J.; Hammerschmidt, W. Structure and role of the terminal repeats of Epstein-Barr virus in processing and packaging of virion DNA. J. Virol. 1995, 69, 3147-3155. [CrossRef]

198. Feederle, R.; Shannon-Lowe, C.; Baldwin, G.; Delecluse, H.J. Defective Infectious Particles and Rare Packaged Genomes Produced by Cells Carrying Terminal-Repeat-Negative Epstein-Barr Virus. J. Virol. 2005, 79, 7641-7647. [CrossRef] [PubMed]

199. Ruiss, R.; Jochum, S.; Wanner, G.; Reisbach, G.; Hammerschmidt, W.; Zeidler, R. A Virus-Like Particle-Based Epstein-Barr Virus Vaccine. J. Virol. 2011, 85, 13105-13113. [CrossRef] 
200. Zhang, X.; Zhao, B.; Ding, M.; Song, S.; Kang, Y.; Yu, Y.; Xu, M.; Xiang, T.; Gao, L.; Feng, Q.; et al. A novel vaccine candidate based on chimeric virus-like particle displaying multiple conserved epitope peptides induced neutralizing antibodies against EBV infection. Theranostics 2020, 10, 5704-5718. [CrossRef]

201. Ngo, M.C.; Ando, J.; Leen, A.M.; Ennamuri, S.; Lapteva, N.; Vera, J.F.; Min-Venditti, A.; Mims, M.P.; Heslop, H.E.; Bollard, C.M.; et al. Complementation of Antigen-presenting Cells to Generate T Lymphocytes with Broad Target Specificity. J. Immunother. 2014, 37, 193-203. [CrossRef]

202. Li, W.; Chen, Q.; Chen, H.; Rao, P.; Xue, X.; Chen, S.; Zhu, S.; Zhang, L. Immune response of mice to a latency membrane protein 2 multiepitope antigen of Epstein-Barr virus applied as DNA vaccine and/or peptide vaccine. Acta Virol. 2013, 57, 51-58. [CrossRef] [PubMed]

203. Guo, R.; Jiang, C.; Zhang, Y.; Govande, A.; Trudeau, S.J.; Chen, F.; Fry, C.J.; Puri, R.; Wolinsky, E.; Schineller, M.; et al. MYC Controls the Epstein-Barr Virus Lytic Switch. Mol. Cell 2020, 78, 653-669. [CrossRef] [PubMed]

204. Van Diemen, F.R.; Kruse, E.M.; Hooykaas, M.J.; Bruggeling, C.E.; Schurch, A.C.; van Ham, P.M.; Imhof, S.M.; Nijhuis, M.; Wiertz, E.J.; Lebbink, R.J. CRISPR/Cas9-Mediated Genome Editing of Herpesviruses Limits Productive and Latent Infections. PLoS Pathog. 2016, 12, e1005701. [CrossRef]

205. Noh, K.-W.; Park, J.; Kang, M.-S. Targeted disruption of EBNA1 in EBV-infected cells attenuated cell growth. BMB Rep. 2016, 49, 226-231. [CrossRef] [PubMed]

206. Sun, C.; Chen, X.-C.; Kang, Y.-F.; Zeng, M.-S. The Status and Prospects of Epstein-Barr Virus Prophylactic Vaccine Development. Front. Immunol. 2021, 12, 677027. [CrossRef] [PubMed]

207. Younger, D.S.; Younger, A.P.; Guttmacher, S. Childhood Vaccination: Implications for Global and Domestic Public Health. Neurol. Clin. 2016, 34, 1035-1047. [CrossRef] [PubMed]

208. Van Wijhe, M.; McDonald, S.A.; de Melker, H.E.; Postma, M.J.; Wallinga, J. Effect of vaccination programmes on mortality burden among children and young adults in the Netherlands during the 20th century: A historical analysis. Lancet Infect Dis. 2016, 16, 592-598. [CrossRef]

209. Rühl, J.; Leung, C.S.; Münz, C. Vaccination against the Epstein-Barr virus. Cell. Mol. Life Sci. 2020, 77, 4315-4324. [CrossRef]

210. Liu, H.; Gemmell, L.; Lin, R.; Zuo, F.; Balfour, H.H., Jr.; Woo, J.C.; Hayes, G.M. Development of an Improved Epstein-Barr Virus (EBV) Neutralizing Antibody Assay to Facilitate Development of a Prophylactic gp350-Subunit EBV Vaccine. Mediterr. J. Hematol. Infect. Dis. 2020, 12, e2020016. [CrossRef] 